\title{
FLEXURAL BEHAVIOR OF HIGH STRENGTH OVER REINFORCED CONCRETE BEAMS UNDER STATIC \& REPEATED LOADING
}

\author{
A. Megahid Ahmed, Khairy Hassan and \\ Mostafa Abd-Elrazek \\ Civil Engineering Department, Faculty of Engineering
}

(Received July 9, 2007, Accepted October 21, 2007)

\begin{abstract}
The Flexural behavior of over reinforced sections is faster grown due to the popular retrofit technique among researchers and engineering worldwide. The main purpose of this work is to give a better and full understanding of the flexural behavior of over reinforced high strength concrete beams subjected to both static and repeated loading. Experimental tests were carried out on different beams having different grades of concrete and percentages of main steel under static or repeated loads. Concrete and steel strains and central deflection of cracking and ultimate loads were recorded for each tested beam. It is shown that the flexural behavior of over reinforced beams under repeated loading is quite different than that under static loading.
\end{abstract}

\section{INTRODUCTION}

Using high percentage of steel reinforcement becomes more evident because reinforced concrete members become more slender in high-rise buildings, bridges and normal construction. High strength concrete began to be developed recently for the use in high-rise building. These developments have contained over the past twenty years or so with concrete 50,70, 100 and $120 \mathrm{~N} / \mathrm{mm}^{2}$ and even higher. According to the ACI building code, the percentage of steel reinforcement is varying from $1 \%$ up to the allowable percentage, which depends on both grades of used concrete and steel reinforcement. The maximum allowable percentage of steel for normal concrete having $\mathrm{F}_{\mathrm{c}}=300 \mathrm{~kg} / \mathrm{cm}^{2}$ and steel with $\mathrm{F}_{\mathrm{y}}=2400 \mathrm{~kg} / \mathrm{cm}^{2}$ varies from $1 \%$ up to $4.7 \%$. However for high strength concrete having $F_{c}=1000 \mathrm{~kg} / \mathrm{cm}^{2}$ and steel with $F_{y}=4000 \mathrm{~kg} / \mathrm{cm}^{2}$, varies from $1 \%$ up to $7 \%$. This indicates that using high strength concrete needs high percentage of steel reinforcement to get full capacity of flexural strength of members. In this paper, the effects of grade of concrete, percentage of main steel ratios $(\mu \%)$ and type of loading on the behavior of high strength concrete reinforced beams under both static and repeated loading are the main goals of the experimental work.

\section{EXPERIMENTAL WORK}

\subsection{Tested Beams:}

This part deals with description of the test specimen, instrumentation and test procedure under static and repeated loading. Test program was mainly intended to 
cover the ranges of static and repeated loading up to failure taking the abovementioned parameters into consideration.

Sixteen of reinforced concrete tested beams having shear span to depth ratio $(\mathrm{a} / \mathrm{d})=3$ with rectangular cross section of $12 \times 20 \mathrm{~cm}$ were tested using two points of loading at the middle third of the beams. These beams were divided into three main groups as follows:

Group A: It includes four beams having the same grade of concrete of $500 \mathrm{~kg} / \mathrm{cm}^{2}$. Each two of them have the same percentage of longitudinal tension reinforcement $(\mu \%)$ and percentage of shear reinforcement, two beams were tested under static loading as control beams and the others two were tested under repeated loading .

Group B: It includes six beams having the same grade of concrete of $700 \mathrm{kglcm}$ with different percentages of main steel and shear reinforcement. Each two beams of them have the same percentage of main longitudinal tension reinforcement $(\mu \%)$, and percentage of shear reinforcement. Three beams were tested under static loading and the others were tested under repeated loading.

Group C: It includes six beams having the same grade of concrete of $800 \mathrm{kglcm}^{2}$ with different percentage of main steel and shear reinforcement. Each two beams have the same longitudinal tension reinforcement $\mu \%$ and same shear reinforcement. Three beams were tested under static loading and the others were tested under repeated loading. All beams were provided with compression steel reinforcement of ( $2 \Phi 10$ $\mathrm{mm}$ ). Details of tested beams are given in Fig(1) and Table (1).

Table (1) :Details of tested beams

\begin{tabular}{|c|c|c|c|c|c|c|c|c|c|c|c|}
\hline & \multirow{2}{*}{$\begin{array}{l}\text { 罚 } \\
\stackrel{3}{3}\end{array}$} & \multirow{2}{*}{\begin{tabular}{|l|} 
Span \\
$\mathrm{cm}$
\end{tabular}} & \multirow{2}{*}{$\begin{array}{c}\mathrm{b} \\
\mathrm{cm}\end{array}$} & \multirow[b]{2}{*}{$\mathrm{cm}$} & \multirow{2}{*}{\begin{tabular}{c|}
$\mathrm{d}$ \\
$\mathrm{cm}$
\end{tabular}} & \multicolumn{2}{|c|}{ Long. Rienf. } & \multirow{2}{*}{ 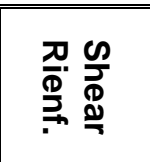 } & \multirow{2}{*}{ is } & \multirow{2}{*}{\begin{tabular}{|c|} 
Grade of \\
concrete \\
Fc \\
kglcm2
\end{tabular}} & \multirow{2}{*}{$\begin{array}{l}\text { Loading } \\
\text { system }\end{array}$} \\
\hline & & & & & & $\mu \%$ & Bottom bar & & & & \\
\hline \multirow{4}{*}{ A } & A21 & 160 & 12 & 20 & 16.9 & 1.98 & 2 фp 16 & $10 \varphi 8 / \mathrm{m}$ & 2фp10 & 500 & Static \\
\hline & A22 & 160 & 12 & 20 & 16.9 & 1.98 & 2 dp 16 & $10 \varphi 8 / \mathrm{m}$ & 2क10 & 500 & Repeated \\
\hline & A11 & 160 & 12 & 20 & 16 & 4.74 & $2 \mathrm{dp} 18+2 \phi 16$ & $10 \varphi 8 / \mathrm{m}$ & 2d10 & 500 & Static \\
\hline & A12 & 160 & 12 & 20 & 16 & 4.74 & $2 \phi 18+2 \phi 16$ & $10 \varphi 8 / \mathrm{m}$ & 2фp10 & 500 & Repeated \\
\hline \multirow{6}{*}{ B } & B21 & 160 & 12 & 20 & 16.9 & 1.98 & 2 ф 16 & $10 \varphi 8 / \mathrm{m}$ & 2q10 & 700 & Static \\
\hline & B22 & 160 & 12 & 20 & 16.9 & 1.98 & 2 d 16 & $10 \varphi 8 / \mathrm{m}$ & 2q10 & 700 & Repeated \\
\hline & B11 & 160 & 12 & 20 & 16 & 4.74 & $2 \phi 18+2 \phi 16$ & $10 \varphi 8 / \mathrm{m}$ & 2q10 & 700 & Static \\
\hline & B12 & 160 & 12 & 20 & 16 & 4.74 & $2 \phi 18+2 \phi 16$ & $10 \varphi 8 / \mathrm{m}$ & 2ф10 & 700 & Repeated \\
\hline & B32 & 160 & 12 & 20 & 15.4 & 8.23 & 4 क 22 & $14 \varphi 8 / m$ & 2q10 & 700 & Static \\
\hline & B31 & 160 & 12 & 20 & 15.4 & 8.23 & 4 क 22 & $14 \varphi 8 / \mathrm{m}$ & 2क10 & 700 & Repeated \\
\hline & $\mathrm{C21}$ & 160 & 12 & 20 & 16.9 & 1.98 & 2 фp 16 & $10 \varphi 8 / m$ & 2q10 & 800 & Static \\
\hline & C22 & 160 & 12 & 20 & 16.9 & 1.98 & 2 фp 16 & $10 \varphi 8 / \mathrm{m}$ & 2фp10 & 800 & Repeated \\
\hline & C11 & 160 & 12 & 20 & 16 & 4.74 & $2 \phi 18+2 \phi 16$ & $10 \varphi 8 / \mathrm{m}$ & 2q10 & 800 & Static \\
\hline & C12 & 160 & 12 & 20 & 16 & 4.74 & $2 \phi 18+2 \phi 16$ & $10 \varphi 8 / \mathrm{m}$ & 2q10 & 800 & Repeated \\
\hline & C32 & 160 & 12 & 20 & 15.4 & 8.23 & 4 ф 22 & $14 \varphi 8 / \mathrm{m}$ & 2q10 & 800 & Static \\
\hline & C31 & 160 & 12 & 20 & 15.4 & 8.23 & 4 ф 22 & $14 \varphi 8 / m$ & 2ф10 & 800 & Repeated \\
\hline
\end{tabular}




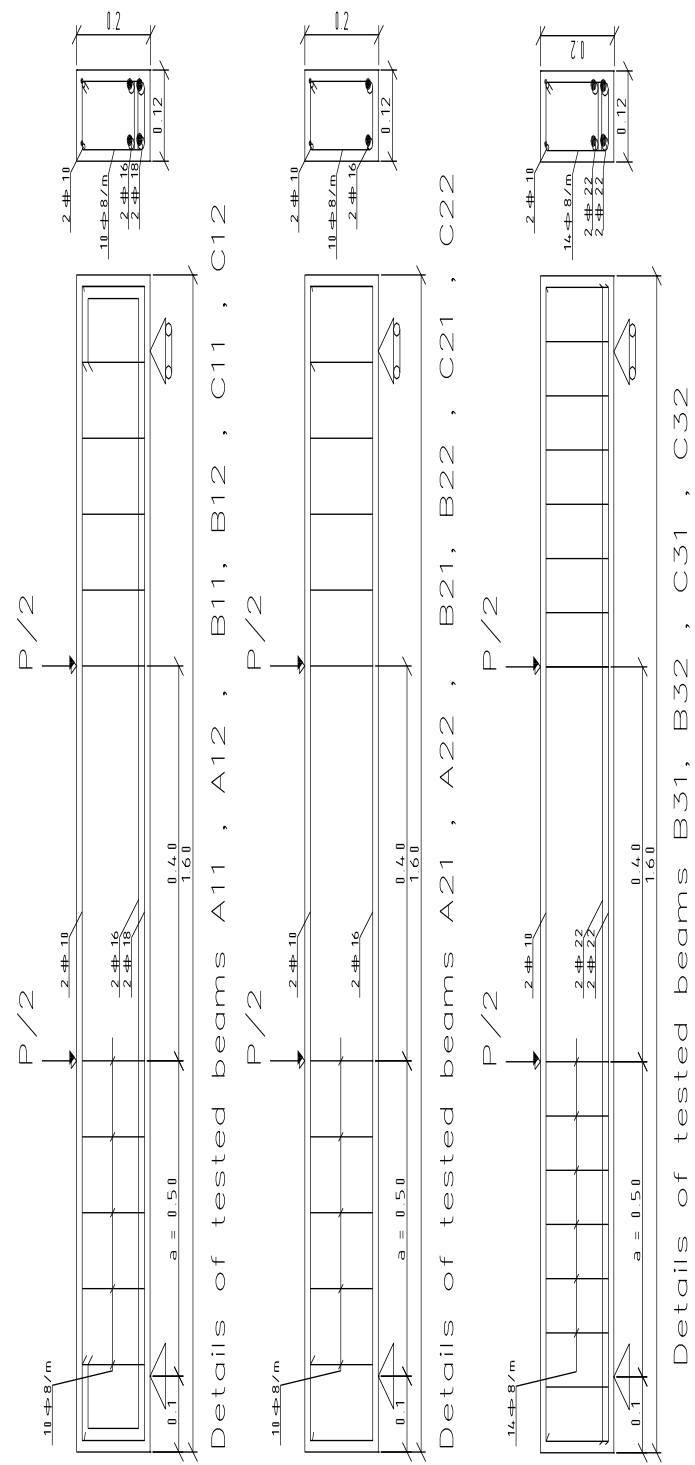

Figure (1) Details of tested beams 


\subsection{Materials:}

Three high strength concrete mixes were designed to produce high strength concrete having 28 days cubic strength of round $505,700 \& 800 \mathrm{Kg} / \mathrm{cm}^{2}$. Concrete mix proportions are given in table (2).

Aggregate: The Coarse aggregate used was crushed basalt \& local natural sand was used as fine aggregate in experimental work. The used crushed basalt \& sand have volume weight of $1.58 \mathrm{t} / \mathrm{m}^{3} \& 1.75 \mathrm{t} / \mathrm{m}^{3}$ respectively. Also it has specific gravity of 2.6 $\& 2.53$ respectively.

Table 2: Concrete mixes proportion by weight

\begin{tabular}{|c|c|c|c|c|c|c||}
\hline $\begin{array}{c}\text { Concrete } \\
\text { mix }\end{array}$ & $\begin{array}{c}\text { Cement } \\
\text { Kg/m3 }\end{array}$ & $\begin{array}{c}\text { Sand } \\
\text { Kg/m3 }\end{array}$ & $\begin{array}{c}\text { Coarse } \\
\text { Agg. } \\
\text { Kg/m3 }\end{array}$ & $\begin{array}{c}\text { Silica } \\
\text { Fume } \\
\text { Kg/m3 }\end{array}$ & $\begin{array}{c}\text { Sikament } \\
\text { Liter/m3 }\end{array}$ & $\begin{array}{c}\text { Water } \\
\text { Liter/m3 }\end{array}$ \\
\hline 1 & 450 & 600 & 1220 & 60 & 10 & 160 \\
\hline 2 & 500 & 575 & 1240 & 75 & 15 & 140 \\
\hline 3 & 550 & 520 & 1260 & 90 & 20 & 135 \\
\hline
\end{tabular}

Cement: Ordinary Portland cement was used (Assiut cement).

Silica fume: Silica fume locally produced by Egyptian Ferro alloys Co. in Edfo city was used.

Water: Drinking water was used for mixing concrete.

Additives: A super plasticizer (ASTM C494 Type F) was used (Sikament 163 for mixes 1 and 2 and Sikament FF for mix 3), Its density is $1.2 \mathrm{~kg} / \mathrm{L}$

Steel reinforcement: The used steel bars, as tension \& compression reinforcement were high grade type bars of 10,16,18,22 mm diameter of proof strength $400 \mathrm{~N} / \mathrm{mm}^{2}$. However mild steel type with diameter $8 \mathrm{~mm}$ and of $330 \mathrm{~N} / \mathrm{mm}^{2}$ yield strength was used for stirrups.

\subsection{Fabrication of Tested Beams:}

Mixing of constituent materials was achieved by means of horizontal pan mixture (liner, 4157 type) of $0,1 \mathrm{~m} 3$ capacity. The dry aggregates, cement and silica fume were firstly mixed for one minute, and the admixture was mixed with water. Mixing was continued until a homogenous mix was obtained. This took about two minutes.

\subsection{Instrumentation:}

The available testing machine ( EMS to 60 tons- up) was used in both static and repeated loading The selected testing machine is provided with heavy steel tare through which the applied load was transmitted to the tested beams through a steel beam $(8 \times 15 \times 50 \mathrm{~cm})$ rested on two supports above the beam. The weight of this tare was 1.4 tons. The used supporting elements were steel hinged and roller supports. These supports were placed at the interface between the beam bottom surface and the fixed head of the testing machine. 
During repeated tests the frequency was chosen to be 500 cycle per minute and the stroke of the working piston was $0.2 \mathrm{~mm}$; and number of cycles $(\mathrm{N})$ was chosen to be 1000000 cycle. Each beam takes 33.3 hour under the repeated loading. The percentage of the applied repeated load to the ultimate static load of control beam was $50 \%$. The loading takes the following steps:

- Static loading began from zero up to $50 \%$ of the ultimate load of the control beam then repeated loading is applied until 500000 cycles then repeated loading was released.

- Further static loading was applied up to 0.5 of the ultimate load of the control beam followed by repeated loading until 1000000 cycle was completed then repeated loading is stopped and released.

- Final static loading was applied from zero up to failure.

The beam deflection was measured using dial gauge with an accuracy of 0.01 $\mathrm{mm}$, fixed at the position of maximum deflection for each beam.

Strains for both concrete and steel were measured at mid span. The strains were measured by using electrical strain gauge having an effective gauge length of 20 $\mathrm{mm}$, while the corresponding values for concrete strain gauges were $60 \mathrm{~mm}$ effective gauge length. Strain gauges connected to a strain indicator (type p3600-1315) for measuring and recording strain values.

\section{RESULTS AND DISCUSSION OF TESTED BEAMS}

\subsection{General behavior of RC flexural beams}

The behavior of RC tested beams generally includes: pattern of cracks, final mode of failure, cracking load, ultimate load, maximum deflection, load-deflection relationship as well as concrete and steel strains up to failure.

As it is known such behavior is mainly affected by some parameters such as:

- Percentage of main reinforcement (section is either under or over reinforced one),

- Shear span to depth ratio,

- Grade of concrete,

- Grade of main steel,

- Configuration and type of shear reinforcement,

- Shape and size of cross section (rect. or T or L section),

- Span to width ratio of beam,

- Type of beam either statically determinate or indeterminate,

- Presence of opening and its size, location and steel around this opening,

- Location of flange and its dimensions, and

- Type of loading either static or repeated. In the current research, the following parameters are only considered:

- Type of loading (static or repeated),

- Percentage of main reinforcement ( $\mu \%=1.98 \%, 4.74 \% \& 8.23 \%)$, and

- Grade of concrete (C 500, C 700 \& C 800). 


\subsection{Effect of Type of Loading on the Behavior of Tested Beams}

\subsubsection{Behavior of Tested Beams under Static Loading}

Eight RC rectangular beams were tested under static loading. The behavior of such beams is as follows:

\section{A) W.R.T Pattern of cracks and modes of failure}

\section{- Group (A) (grade of concrete C $500 \mathrm{~kg} / \mathrm{cm} 2$ )}

For beam A 2-1 ( $\mu \%=1.98$, under reinforced section), the first crack is occurred in the tension zone at load $\mathrm{P}=4.5$ ton ( $36 \%$ of ultimate loading) and extended vertical to the neutral axis. Number of cracks increased at the middle third and shear cracks appeared at $\mathrm{P}=7.5$ ton $(60 \%$ of ultimate loading). The middle third concrete at compression zone was crushed. The major crack appeared at the middle span approximately in vertical direction. The beam was failed with flexural-compression mode. as shown in photo (1)

For beam A 1-1 $(\mu \%=4.74$, over reinforced section) the first crack was in tension zone at load $\mathrm{p}=6.5$ ton, (29.5\% of ultimate loading). Shear crack appeared at load $\mathrm{P}=$ 12.0 ton, (54.5\% of ultimate loading) and it was started beside the support point and towards the point of loading. The concrete at compression zone was crushed. Buckling of the compression steel occurred at the middle third of the beam. The beam was failed with flexural-compression mode. as shown in photo (2)

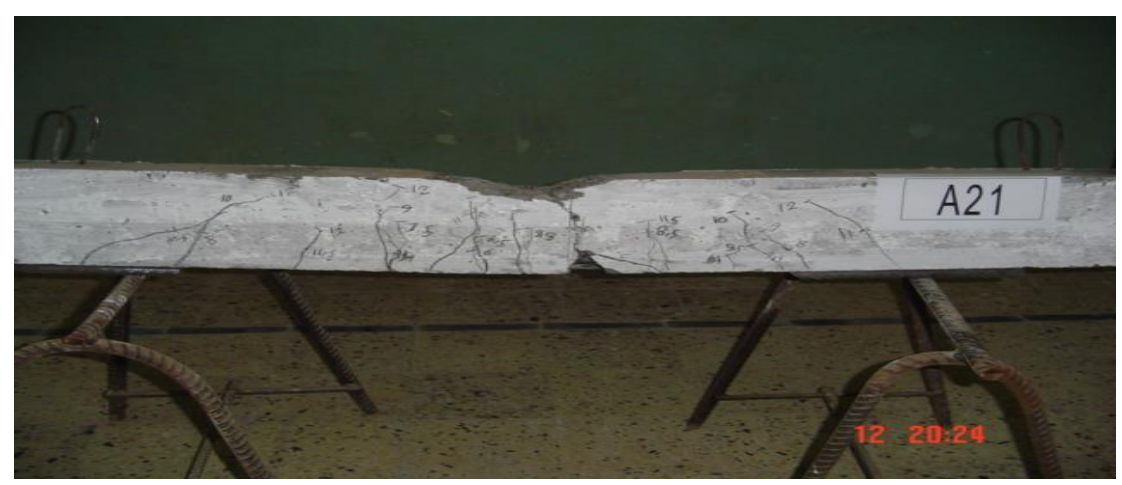

Photo (1): Behavior of Beam A 2-1

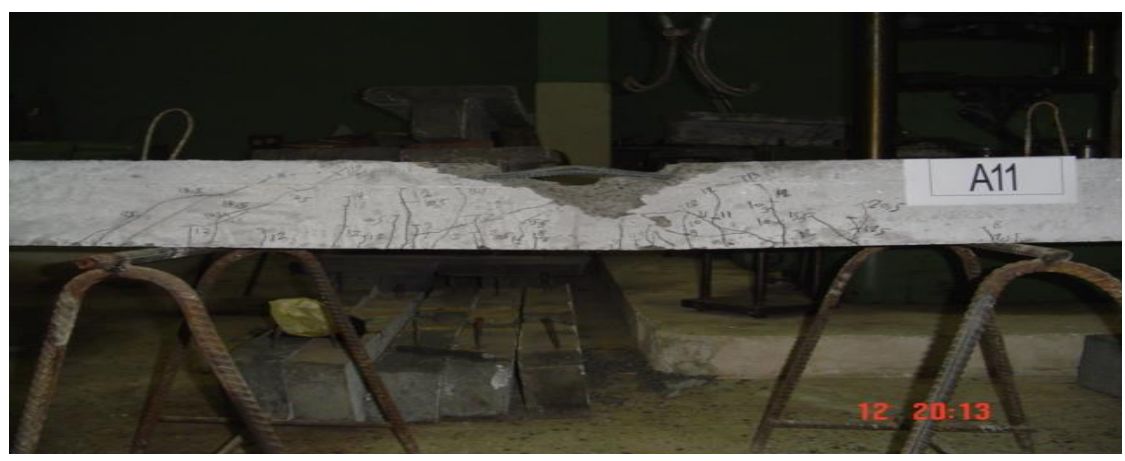

Photo (2): Behavior of Beam A 1-1 


\section{- Group (B) (grade of concrete C $700 \mathrm{~kg} \backslash \mathrm{cm} 2$ )}

For beam B2-1 $(\mu \%=1.98$, under reinforced section), the first crack was tension crack. It is appeared at load $\mathrm{P}=3$ ton at $19.8 \%$ of ultimate loading. Number of cracks increased at the middle third, shear cracks appeared at load $\mathrm{P}=9.5 \mathrm{t}$, at $62.9 \%$ of ultimate loading. The concrete at compression zone was crushed. The beam was failed with flexural- compression mode. as shown in photo (3).

For beam B1-1 $(\mu \%=4.74$, over reinforced section), the first crack was tension crack, it was appeared at the mid of span, at load $\mathrm{P}=7.5 \mathrm{t}$, at $31.1 \%$ of ultimate loading. Further shear cracks were appeared at load $\mathrm{P}=11 \mathrm{t}$, at $45.6 \%$ of ultimate loading and then were started beside the support point and extended up to the loading point. The major crack appeared at shear zone with inclination with vertical direction. The beam was failed with shear mode. as shown in photo (4).

For beam B3-2 ( $\mu \%=8.23$, over reinforced section), the first crack was tension crack under the loading point. It was appeared at load $\mathrm{P}=6.0 \mathrm{t}$, at $21.7 \%$ of ultimate loading. Cracks at mid span have a small height but cracks under the two point of loading have a great height and width. Shear cracks were appeared at load $\mathrm{P}=13 \mathrm{t}$, at $47.1 \%$ of ultimate loading. The major crack was appeared at load $\mathrm{P}=16.5 \mathrm{t}$. it began immediately with a big width beside the support point. The major crack propagated diagonally. The concrete at compression zone was crushed at the top of the major crack. The beam was failed with shear- compression mode. as shown in photo (5).

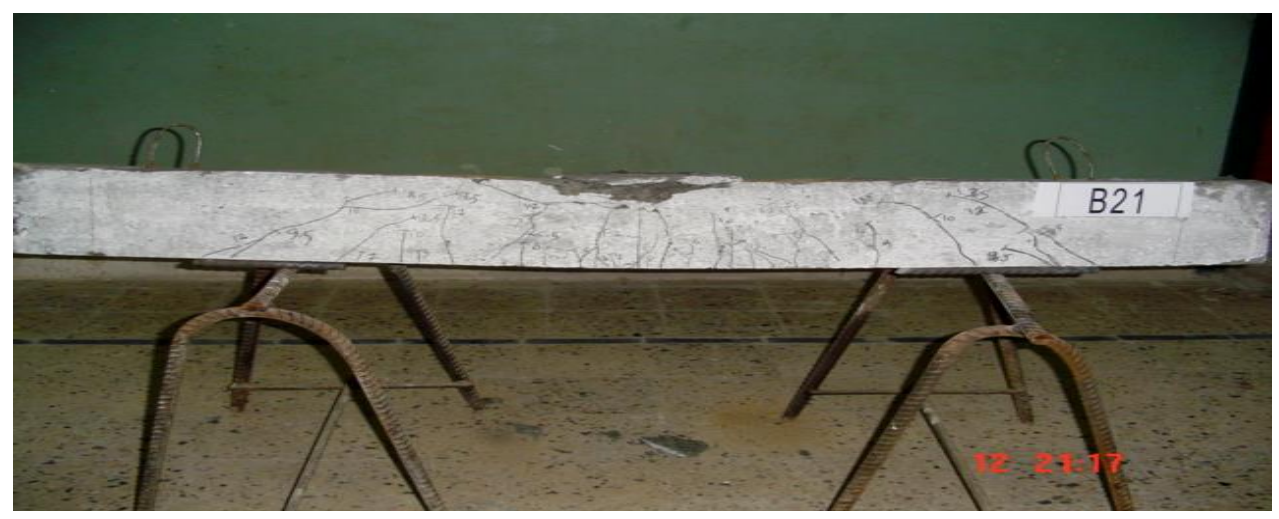

Photo (3): Behavior of Beam B 2-1

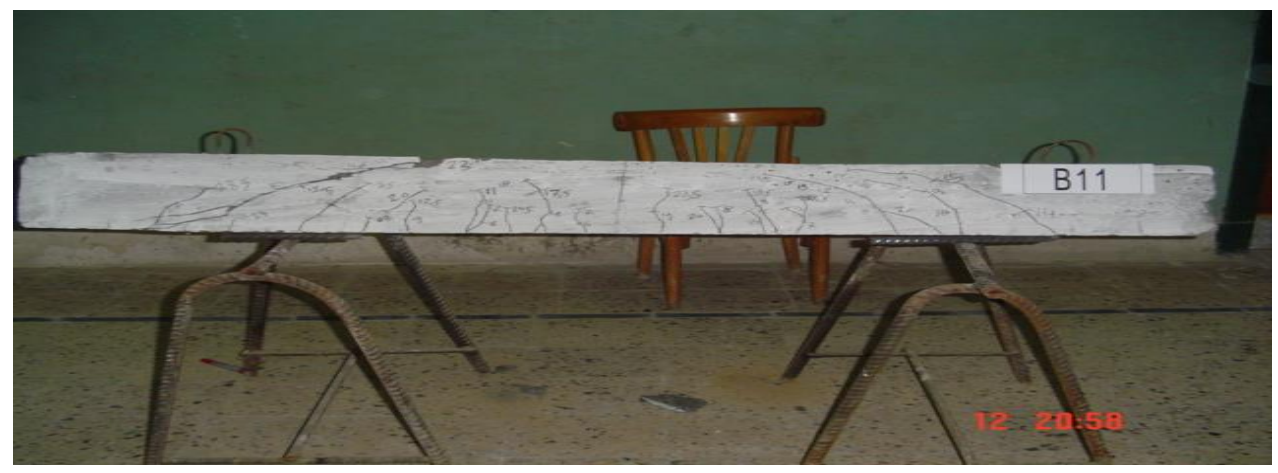

Photo (4): Behavior of Beam B 1-1 


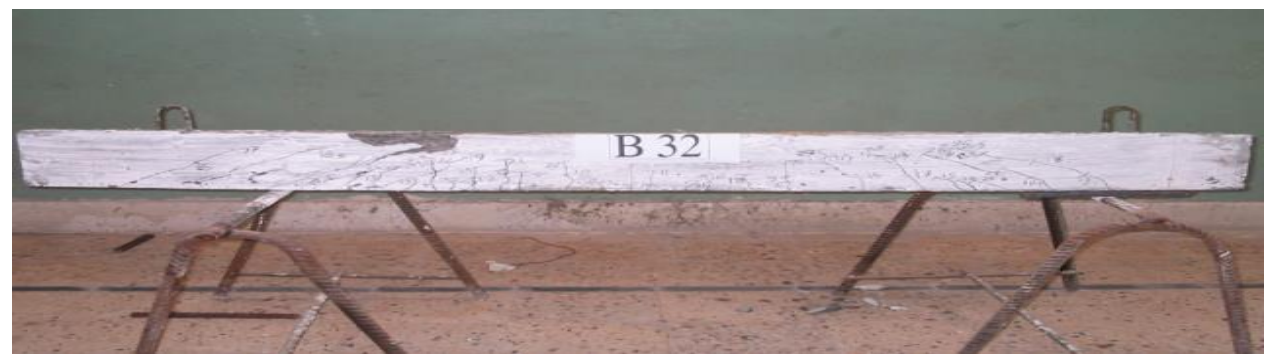

Photo (5): Behavior of Beam B 3-2

\section{- Group (C) (grade of concrete C $800 \mathrm{~kg} \mid \mathrm{cm} 2$ )}

For beam C 2-1 ( $\mu \%=1.98$, under reinforced section), the first crack was tension crack. It is appeared at load $\mathrm{P}=4 \mathrm{t}$ at $28.5 \%$ of ultimate loading. Shear cracks appeared at load $\mathrm{P}=7 \mathrm{t}$ at $50 \%$ of ultimate loading. The concrete at compression zone was crushed under the point of loading. The major crack appeared at right half of middle third. The beam was failed with flexural-compression mode as shown in photo (6).

For beam C 1-1 $(\mu \%=4.74$, over reinforced section), the first crack was tension crack, it was appeared at the middle third of the span, at load $\mathrm{P}=6 \mathrm{t}$, at $22.6 \%$ of ultimate loading. The first crack stopped. A lot of cracks were appeared under the two points of loading and at middle third of span with a great height. Shear cracks was appeared at load $\mathrm{P}=13.5 \mathrm{t}$, at $50.9 \%$ of ultimate loading and it was started from the supported point. The compression zone of the concrete section at the middle third was crushed. The beam was failed with flexural- compression mode as shown in photo (7).

For Beam C 3-2 ( $\mu \%=8.23$, over reinforced section), the first crack was tension crack at the middle third. It was appeared at load $\mathrm{P}=7 \mathrm{t}$, at $25.1 \%$ of ultimate loading. A lot of cracks were appeared under the two points of loading. Shear cracks were appeared at load $\mathrm{P}=14 \mathrm{t}$, at $50.1 \%$ of ultimate loading. Nothing happened to the concrete at compression zone at middle third but the concrete at compression zone was crushed at the top of the major crack. The major inclined crack was appeared at load P $=15.5 \mathrm{t}$. It began beside the left support. The beam failed with shear-compression mode as shown in photo (8).

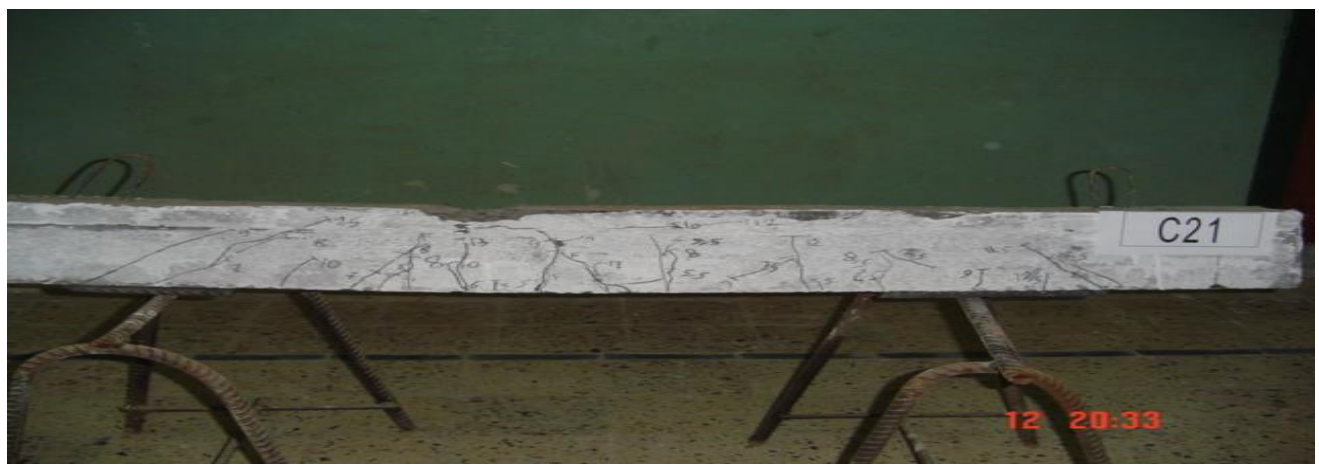

Photo (6): Behavior of Beam C 2-1 


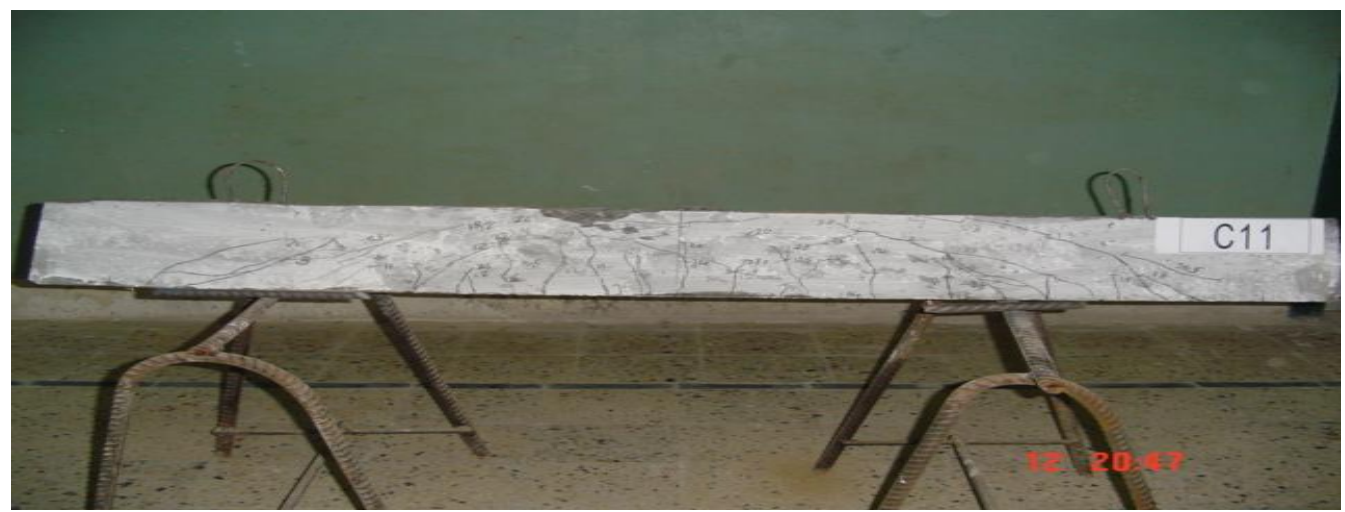

Photo (7): Behavior of Beam C 1-1

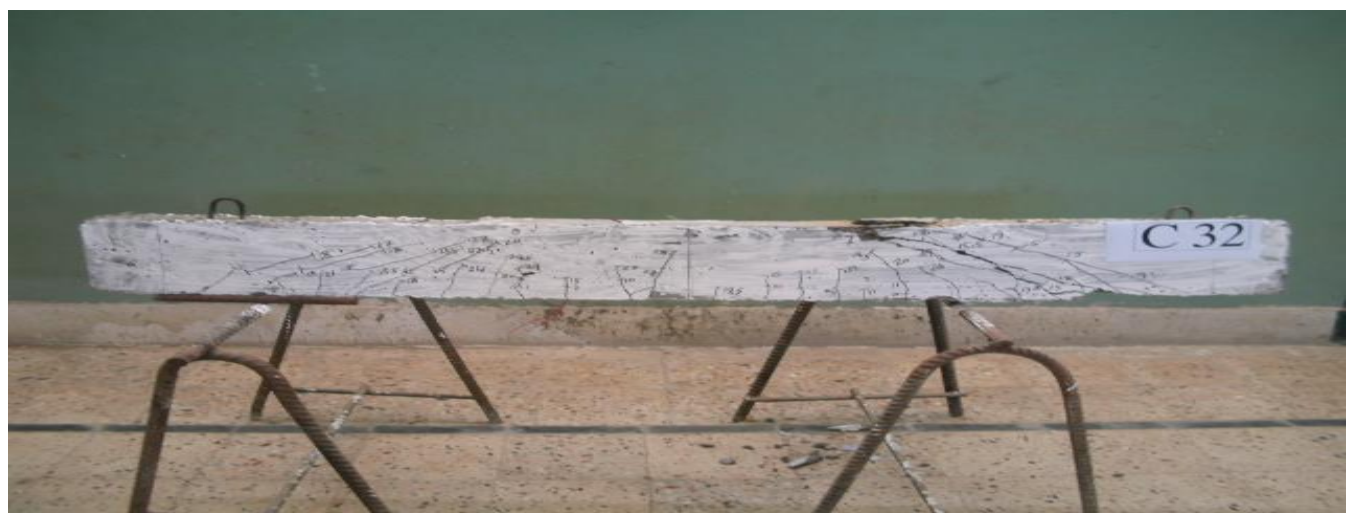

Photo (8): Behavior of Beam C 3-2

\section{B) W.R.T Load deformations diagrams:}

Figures 2, 3, and 4 show a plot between the static applied load and the corresponding values of the recorded maximum deflection, maximum concrete strain and maximum values of steel strain, respectively. 

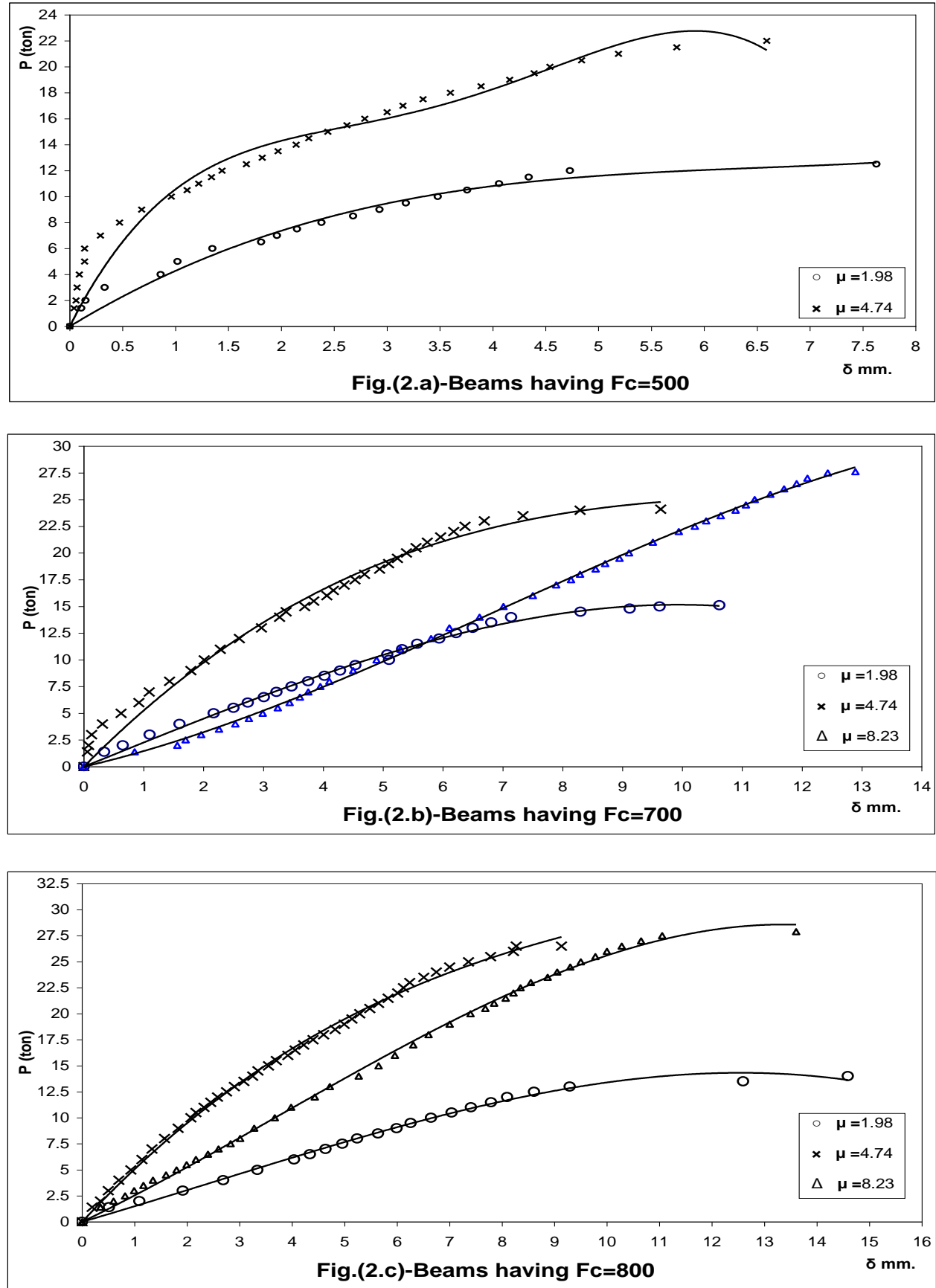

Figure (2) Load maximum deflection relationship for static loading 

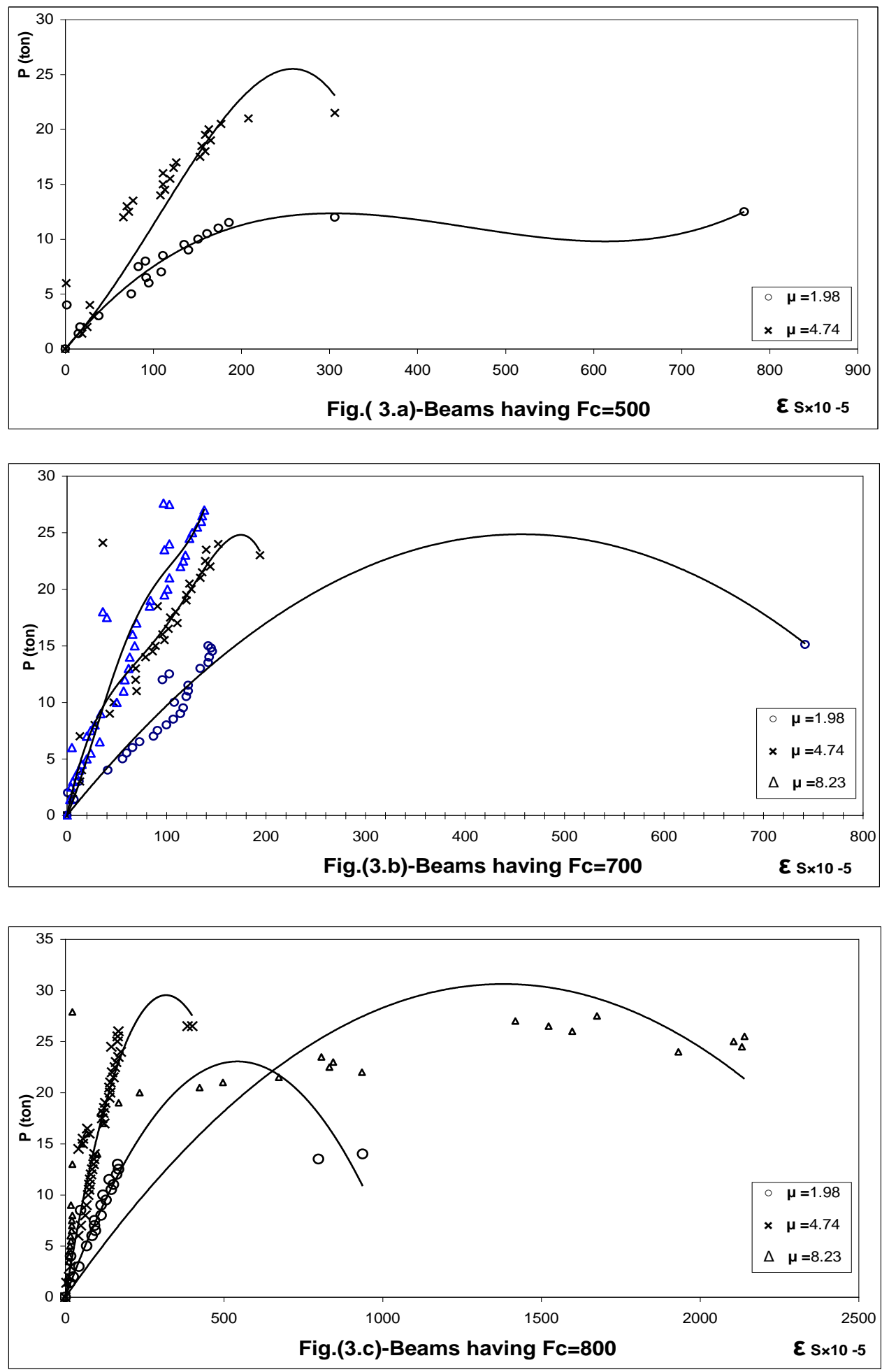

Figure (3) Load maximum steel strain relationship for static loading 

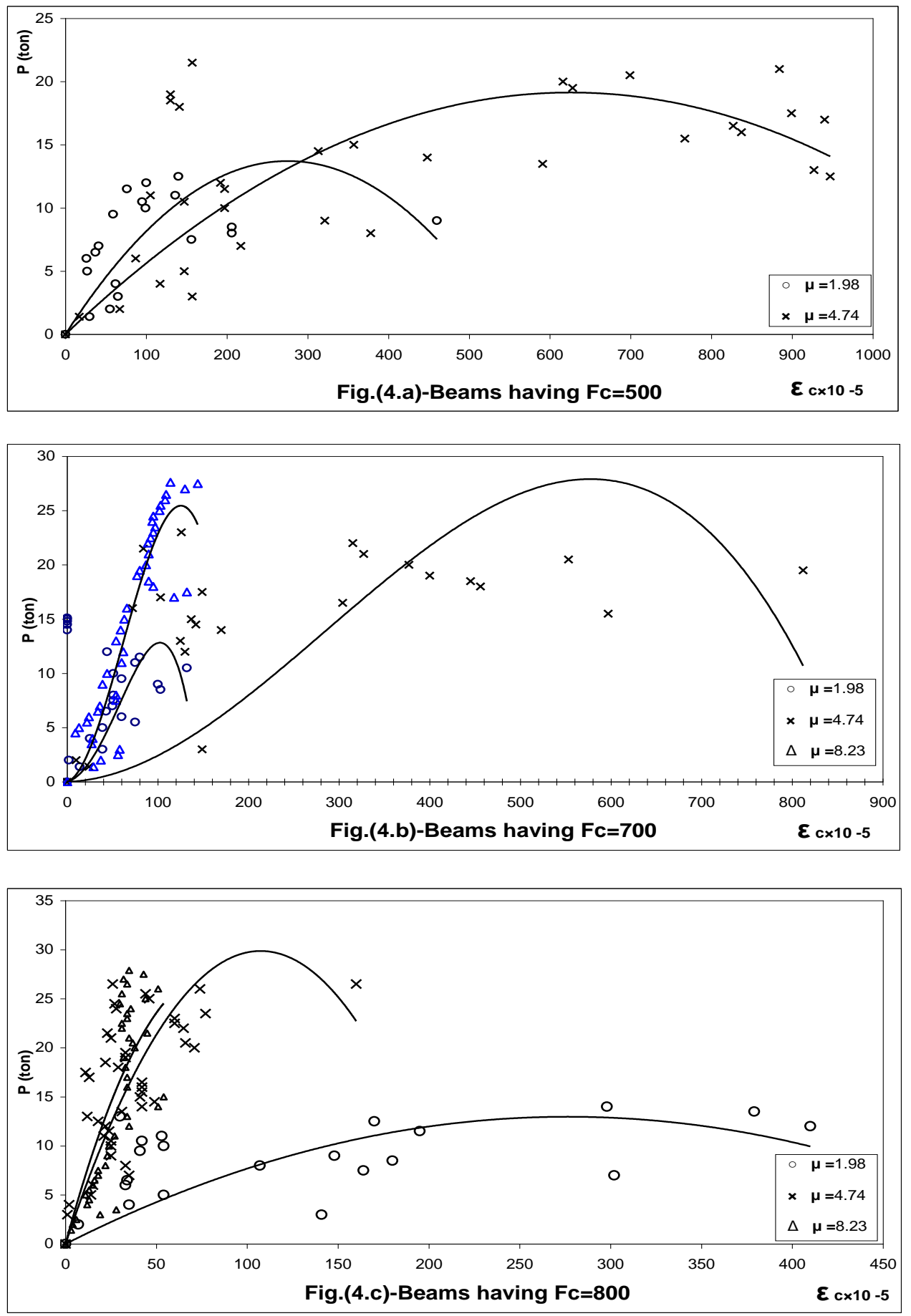

Figure (4) Load maximum concrete strain relationship for static loading 
Table (3) summarizes the obtained values of cracking load, ultimate load, ultimate concrete strain and ultimate steel strain as well as the modes of failure for static loading tested beams.

Table (3): Test results for static loading

\begin{tabular}{|c|c|c|c|c|c|c|c|c|c|c|}
\hline Beam & $\begin{array}{c}\mathrm{Fc} \\
\mathrm{kg} / \mathrm{cm} 2\end{array}$ & $\mu \%$ & $\begin{array}{c}\text { Type } \\
\text { of } \\
\text { beam }\end{array}$ & $\begin{array}{l}\text { Pcrs } \\
\text { (ton) }\end{array}$ & $\begin{array}{l}\text { Pus } \\
\text { (ton) }\end{array}$ & $\begin{array}{l}\text { Pcrs / } \\
\text { Pus }\end{array}$ & $\begin{array}{l}\text { Maximum } \\
\text { steel strain } \\
\times 10.5 \text { (Zs)s }\end{array}$ & $\begin{array}{l}\text { Maximum } \\
\text { concrete } \\
\text { strain } \times 10-5 \\
\text { (उc)s }\end{array}$ & $\begin{array}{l}\text { Maximum } \\
\text { deflection } \\
(\mathrm{mm})(\delta) \mathrm{s}\end{array}$ & Mode of failure \\
\hline A2-1 & \multirow{2}{*}{500} & 1.98 & under & 4.5 & 12.5 & 0.36 & 771 & 460 & 7.63 & Flexural-compression \\
\hline A1-1 & & 4.74 & over & 6.5 & 22 & 0.30 & 306 & 947 & 6.59 & Flexural-compression \\
\hline B2-1 & \multirow{3}{*}{700} & 1.98 & under & 3 & 15.1 & 0.20 & 742 & 132 & 10.62 & Flexural-compression \\
\hline$B 1-1$ & & 4.74 & over & 7.5 & 24.1 & 0.31 & 194 & 812 & 9.64 & Shear \\
\hline B3-2 & & 8.23 & over & 6 & 27.6 & 0.22 & 138 & 144 & 13.99 & Shear-compression \\
\hline C2-1 & \multirow{3}{*}{800} & 1.98 & under & 4 & 14 & 0.29 & 937 & 410 & 14.59 & Flexural-compression \\
\hline C1-1 & & 4.74 & over & 6 & 26.5 & 0.23 & 400 & 160 & 9.17 & Flexural-compression \\
\hline C3-2 & & 8.23 & over & 7 & 27.9 & 0.25 & 132 & 54 & 13.6 & Shear-compression \\
\hline
\end{tabular}

Figures (5) to (16) declared how the \% of main steel as well as the grade of concrete affects the behaviour of such beams items of cracking load $\left(\mathrm{P}_{\mathrm{cr}}\right)$, ultimate load $\left(\mathrm{P}_{\mathrm{u}}\right), \%$ of $\left(\mathrm{P}_{\mathrm{cr}} / \mathrm{P}_{\mathrm{u}}\right)$ and ultimate deformation of concrete and steel. Investigation of such figures and on the light of Table (3), the following remarks are observed:

\section{a) Effect of Main Steel Percentage $(\mu \%)$ :}

\section{- W.R.T Cracks and Final Modes of Failure}

At constant grade of concrete $F_{c}=500$, The increasing of main steel percentage $(\mu)$ does not make changes in the mode of failure but at $F_{c}=700$ the increase of main steel percentage $(\mu)$ from 1.98 to 4.74 to 8.23 changes the mode of failure from flexuralcompression failure to shear failure to shear-compression failure, However at $F_{c}=800$ the increase of main steel percentage ( $\mu$ ) from 1.98 to 4.74 don't change the mode of failure (flexural-compression mode), but the increase up to $\mu=8.23 \%$ changed the mode of failure to shear-compression failure

\section{- W.R.T Cracking load (Pcrs) :}

For the same concrete strength, the increase of main steel percentage $\mu \%$ increases the cracking load value as shown in fig.(11)

\section{- W.R.T Ultimate load (Pus) :}

For the same concrete strength, the increase of main steel percentage $\mu \%$ increases the ultimate load value as shown in fig.(12)

\section{- W.R.T \% Of Cracking load to Ultimate load (Pcrs/Pus)\% :}

For the same concrete strength the increase of main steel percentage $\mu \%$ decreases the \% of cracking load to ultimate load value as shown in fig.(13) 


\section{- W.R.T Maximum deflection $(\delta) s$ :}

For constant concrete strength, the maximum deflection usually decreases by increasing the percentage of main steel value $\mu$ until $\mu=4.74 \%$ but it is observed that beyond this value the maximum deflection increased as shown in fig.(14).

\section{- W.R.T Maximum steel $\operatorname{strain}(\zeta \mathrm{s}) \mathrm{s}$ :}

For constant concrete strength, the maximum steel strain usually decreases by increasing the percentage of main steel value $(\mu)$ as shown in fig.( 15 ).

\section{- W.R.T Maximum concrete $\operatorname{strain}(\zeta \mathrm{c}) \mathrm{s}$ :}

For constant concrete strength $\mathrm{F}_{\mathrm{c}}=500$ and 700 , the maximum concrete strain increases by increasing the percentage of main steel $(\mu)^{\prime}$ until $\mu=4.74$ but beyond this value the maximum concrete strain decreased by increasing the percentage of main steel value. For constant $F_{c}=800$, as $(\mu)$ increases the concrete strain decreases value. as shown in fig.(16)

\section{b) Effect of Grade of Concrete (Fc) on:}

\section{- W.R.T Cracks and Final Modes of Failure:}

For $\mu=1.98 \%$ the increase of grade of concrete from 500 to $800 \mathrm{Kg} / \mathrm{cm}^{2}$ has no effect on the mode of failure where it was flexural compression failure. However $\mu=4.74 \%$ the increase of grade of concrete from 500 to $800 \mathrm{Kg} / \mathrm{cm}^{2}$ changed the mode of failure from flexural compression mode to shear mode to flexural compression. Main while for $\mu=8.23 \%$ the increase of grade of concrete from 700 to $800 \mathrm{Kg} / \mathrm{cm}^{2}$ has no effect on the mode of failure.

\section{- W.R.T Cracking load(Pcrs):}

Generally, the cracking load value increases increasing the grade of concrete. The rate of increase mainly depends on the value of the \% of main reinforcements as shown in fig. $(5,11)$.

\section{- W.R.T Ultimate loading(Pus):}

Fig.(6) shows the relation between the ultimate load $(\mathrm{Pu})$ versus the used grade of concrete for different values of main reinforcements ratio $(\mu) \%$. As a general rule for a given $\%$ of main reinforcement ratio $(\mu) \%$, the increase of concrete grade is usually accompanied with an increase in the corresponding ultimate load (see fig. 12).

\section{- W.R.T \% Of Cracking load to Ultimate load(Pcrs/Pus)\%:}

Fig.(7) shows that the ratio of cracking to ultimate load ranged between $0.25 \%$ to $0.35 \%$ varying according to both grade of concrete and $\%$ of main reinforcement ratio ( $\mu$ ) (see fig. 13).

\section{- W.R.T Maximum Induced Deformations:}

Fig. $(8,9 \& 10)$ illustrate the relation between the induced deformations in form of maximum deflection $(\delta)$, maximum steel $\operatorname{strain}(\zeta \mathrm{s})$ and maximum concrete $\operatorname{strain}(\zeta \mathrm{c})$, where it is obvious that these is no doubt that these values varies by means of the variation of both grade of concrete and \% of main reinforcement ratio $(\mu)$ (see fig. $14,15 \& 16)$. 


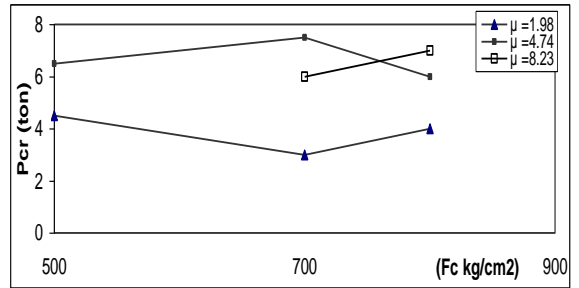

Fig. (5) Relation between cracking load and grade of concrete for static loading

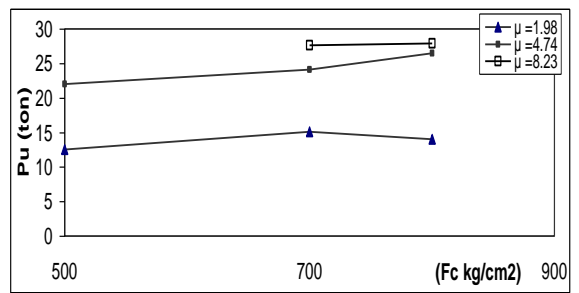

Fig. (6) Relation between ultimat load and grade of concrete for static loading

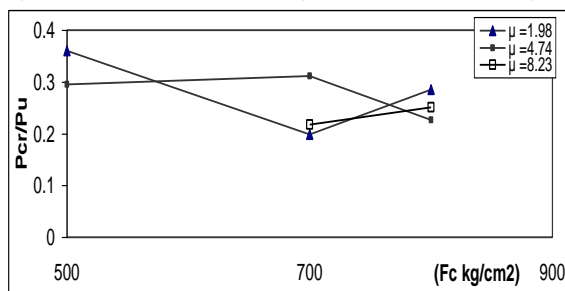

Fig.(7) Relation between \% Pcr/Pu and grade of concrete for static loading

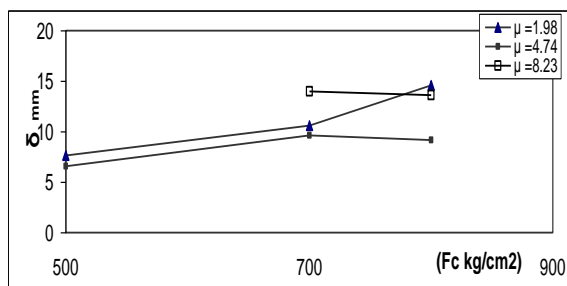

Fig.(8) Relation between max. deflection and grade of concrete for static loading

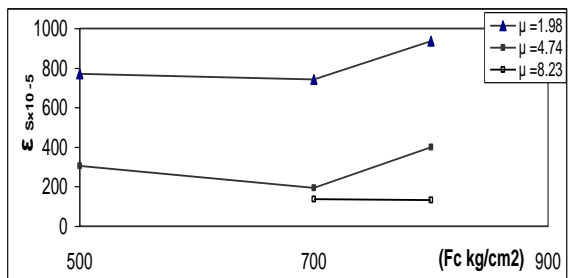

Fig.(9) Relation between max. steel strain and grade of concrete for static loading

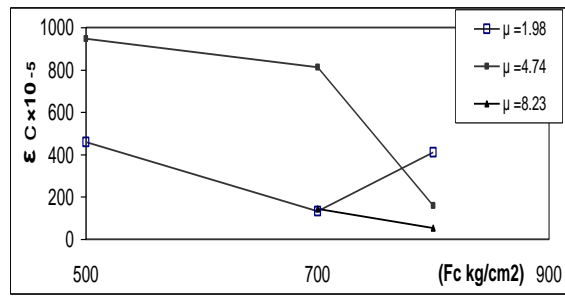

Fig.(10) Relation between max. concrete strain and grade of concrete for static loading

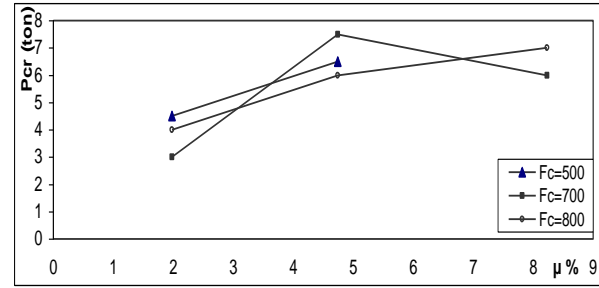

Fig.(11) Relation between cracking load and \% of reinforcement for static loading

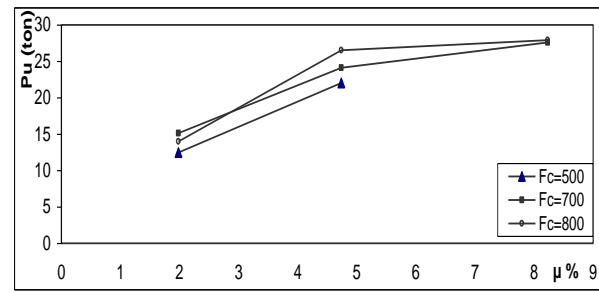

Fig. (12) Relation between ultimat load and \% of reinforcement for static loading

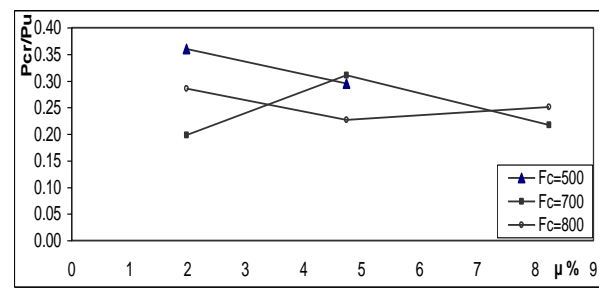

Fig.(13) Relation between \%Pcr/pu and \% of reinforcement for static loading

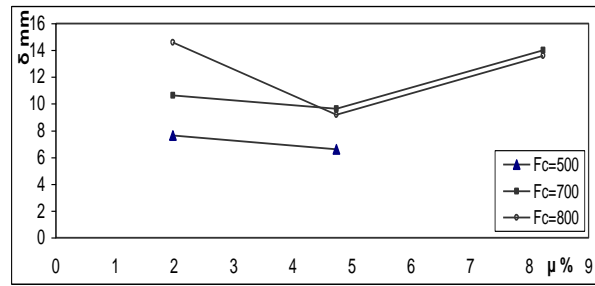

Fig.(14) Relation between max. deflection and \% of reinforcement for static loading

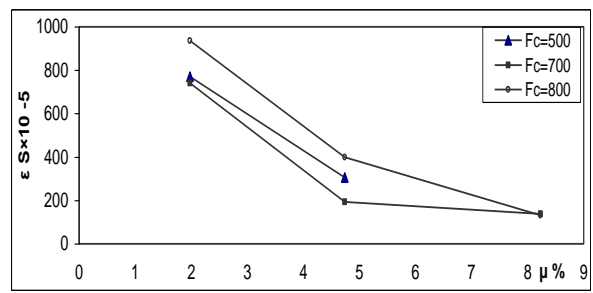

Fig.(15) Relation between max. steel strain and \% of reinforcement for static loading

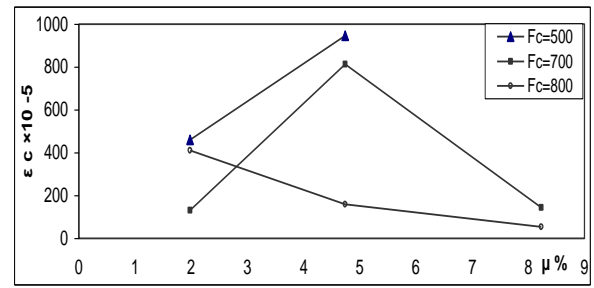

Fig.(16) Relation between max. concrete strain and \% of reinforcement for static loading 


\subsubsection{Behavior of Tested Beams under Repeated Loading}

Eight rectangular beams were tested under repeated loading. The behavior of the eight beams includes the initiation of cracks and their propagation as well as load-deflection relations were mentioned as below:

\section{A. W.R.T Pattern of cracks and modes of failure}

\section{- Group (A) ( grade of concrete C $500 \mathrm{~kg} \backslash \mathrm{cm} 2$ )}

For beam A 2-2 ( $\mu \%=1.98$, under reinforced section) the cracks during the first static load cycle were similar to that which occurred in the control beam under static load. During the repeated cycles the cracks length, width and number were increased. The first crack appeared at $\mathrm{P}=6.5$ ton at $49.2 \%$ of the ultimate load. The beam failed with flexural-compression mode like the control beam. as shown in photo( 9 )

For beam A 1-2 $(\mu \%=4.74$,over reinforced section) The First crack was tension crack. It was appeared at load $p=6.8$ ton, at $31.1 \%$ of ultimate load. During the repeated cycles the cracks length, width and number were increased. Shear crack was appeared at load $\mathrm{P}=7 \mathrm{t}$. The beam failed with shear mode type. as shown in photo( 10 )

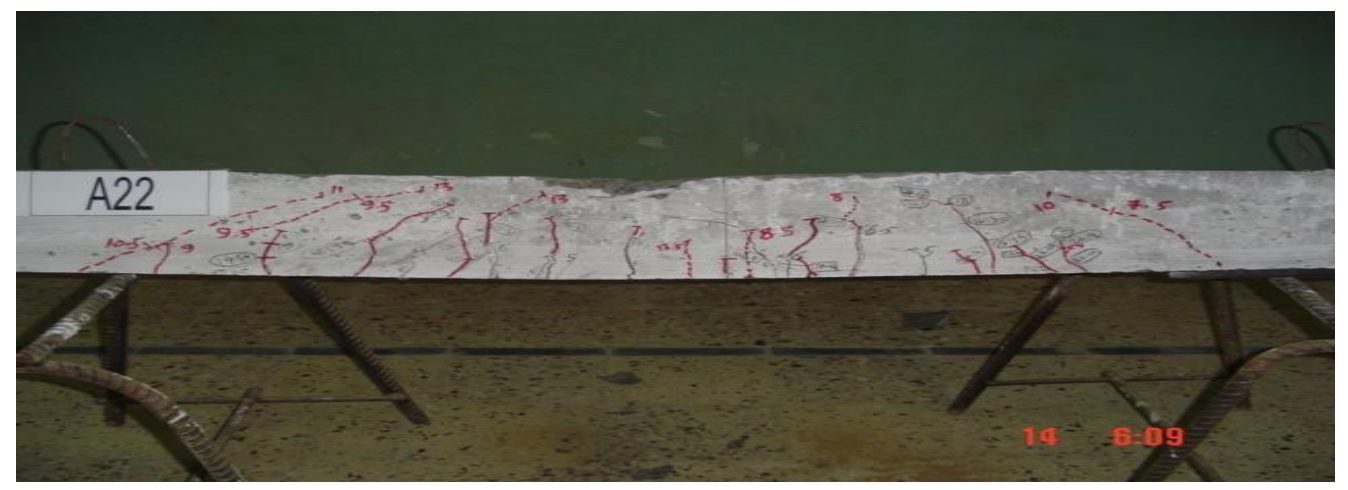

Photo (9): Behavior of Beam A 2-2

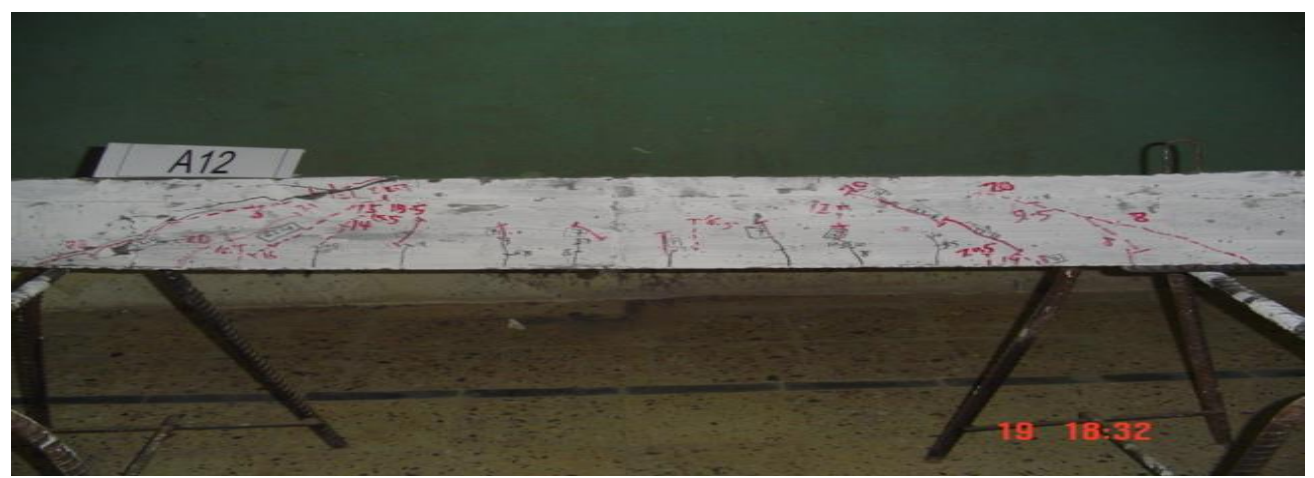

Photo (10): Behavior of Beam A 1-2 
- Group B ( grade of concrete C $700 \mathrm{~kg} \backslash \mathrm{cm} 2$ )

For beam B 2-2 ( $\mu \%=1.98$, under reinforced section) the cracks during the first static load cycle were similar to that which occurred in the control beam under static load. The first crack appeared at load $\mathrm{P}=4$ ton at $25.8 \%$ of ultimate load. A slight increase was noticed on the cracks length, width and number during the repeated cycles. The beam failed with flexural-compression mode. as shown in photo( 11 )

For beam B 1-2 ( $\mu \%=4.74$, over reinforced section) the first crack was appeared at load $\mathrm{P}=5.5$ ton, at $22.7 \%$ of ultimate loading. During the repeated cycles the cracks propagated and increased at the shear span accompanied with little cracks appeared at the flexural span. The beam failed with shear-compression mode as that occurred in control beam. as shown in photo( 12$)$

For Beam B 3-1 $(\mu \%=8.23$, over reinforced section) the cracks during the first static load cycle were similar to that which occurred in the control beam under static load. the first crack was appeared at load $\mathrm{P}=6.5$ ton, at $25.0 \%$ of ultimate loading. During the repeated cycles the cracks propagated and increased at both shear span and flexural span. The beam failed in shear-compression mode. as shown in photo( 13 )

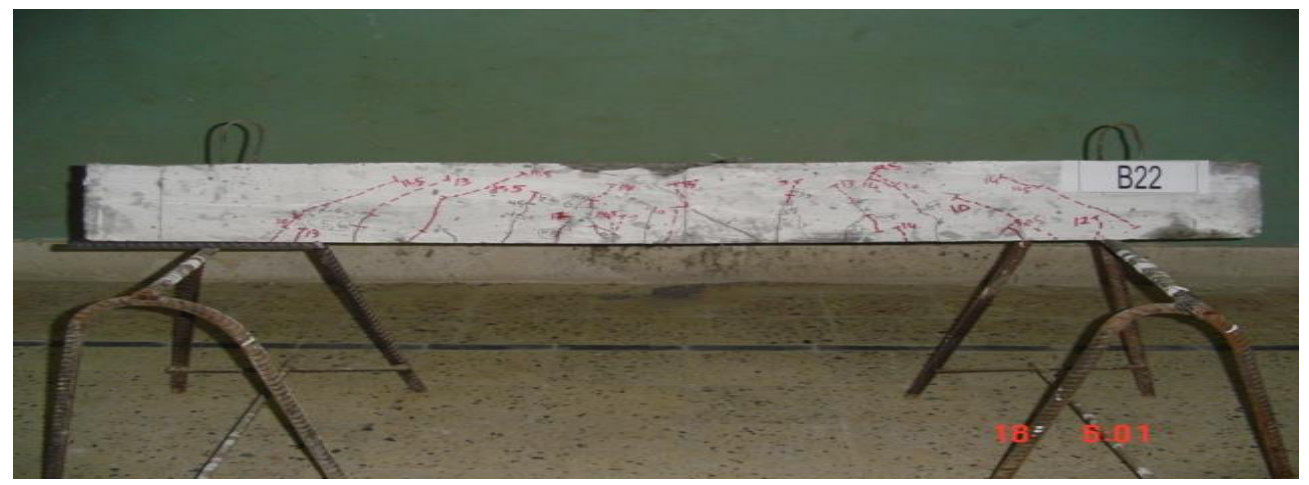

Photo (11): Behavior of Beam B 2-2

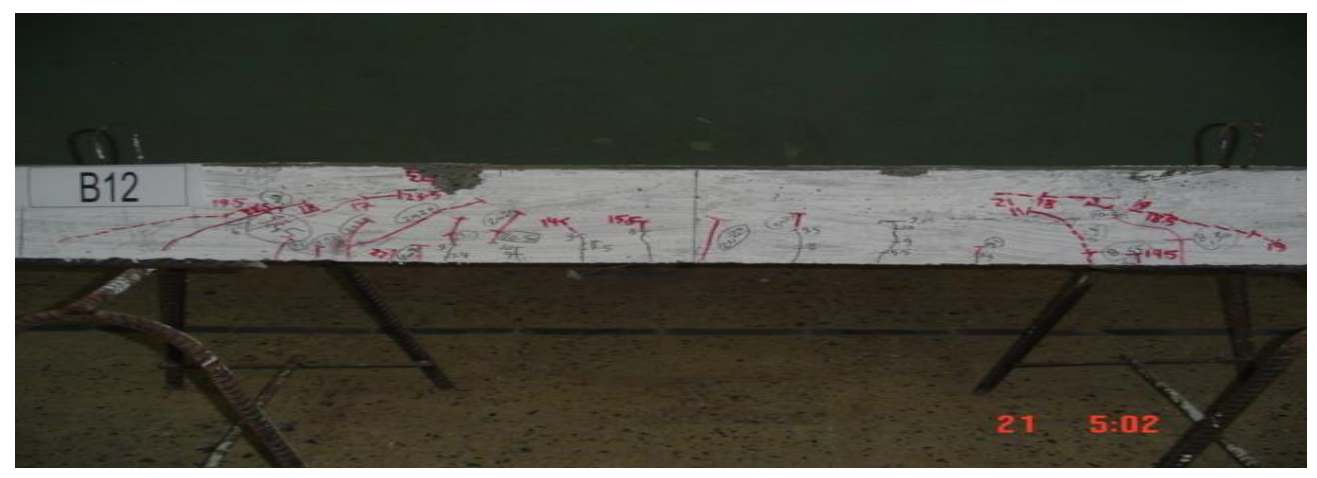

Photo (12): Behavior of Beam B1-2 


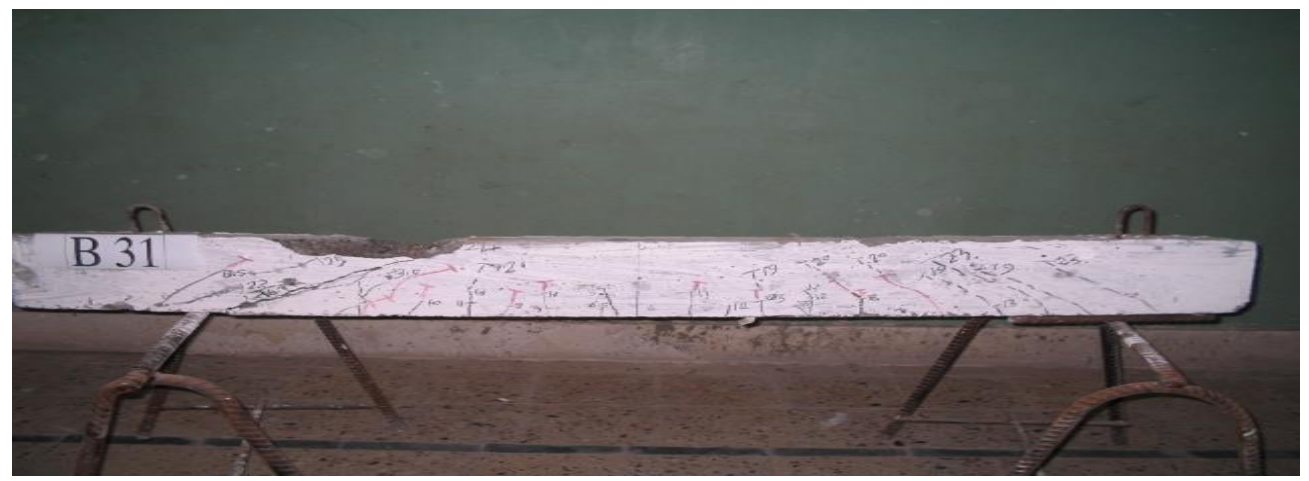

Photo (13): Behavior of Beam B 3-1

\section{- Group C ( grade of concrete C $800 \mathrm{~kg} / \mathrm{cm} 2$ )}

For beam C 2-2( $\mu \%=1.98$, under reinforced section) the cracks during the first static load cycle were similar to that which occurred in the control beam under static load. The first crack appeared at load $\mathrm{P}=3$ ton at $22.2 \%$ of ultimate load. A great increase was noticed on the cracks length, width and number during the repeated cycles. The beam failed with flexural-compression mode as that occurred in control beam. as shown in photo( 14 )

For beam C 1-2 ( $\mu \%=4.74$, over reinforced section) the cracks during the first static load cycle were similar to that which occurred in the control beam under static load. The first crack appeared at load $\mathrm{P}=3.6$ ton and $14.5 \%$ of ultimate load. Further, Shear cracks were appeared and increased in length, width and number during the repeated cycles. The beam failed with flexural-compression mode. as shown in photo( 15 )

For Beam C 3-1 $(\mu \%=8.23$, over reinforced section $)$ the first crack was tension crack at the middle third. It was appeared at load $\mathrm{P}=7$ ton and $22.7 \%$ of ultimate. The cracks during the first static load cycle were similar to that which occurred in the control beam under static load. Further, Shear cracks were appeared and increased in length, width and number during the repeated cycles. The beam failed in shearcompression mode similar to that occurred in control beam. as shown in photo( 16 )

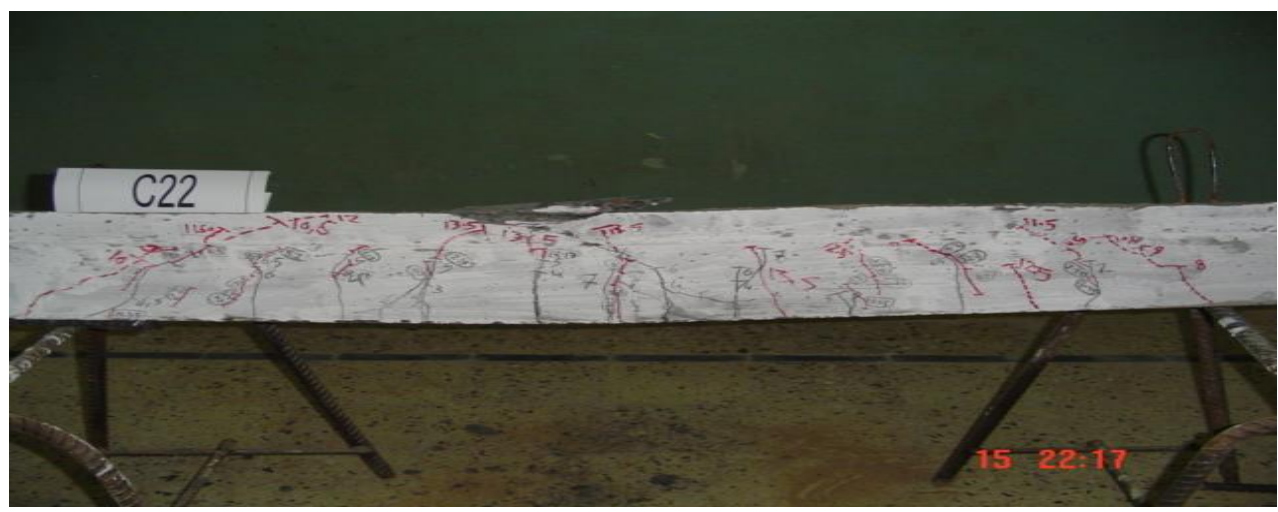

Photo (14): Behavior of Beam C 2-2 


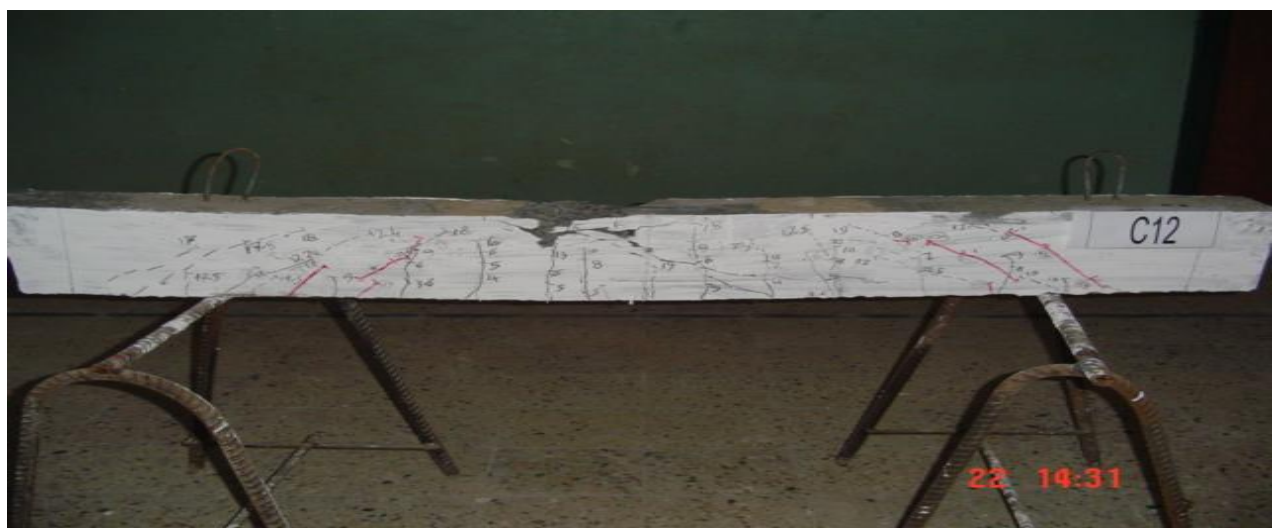

Photo (15): Behavior of Beam C 1-2

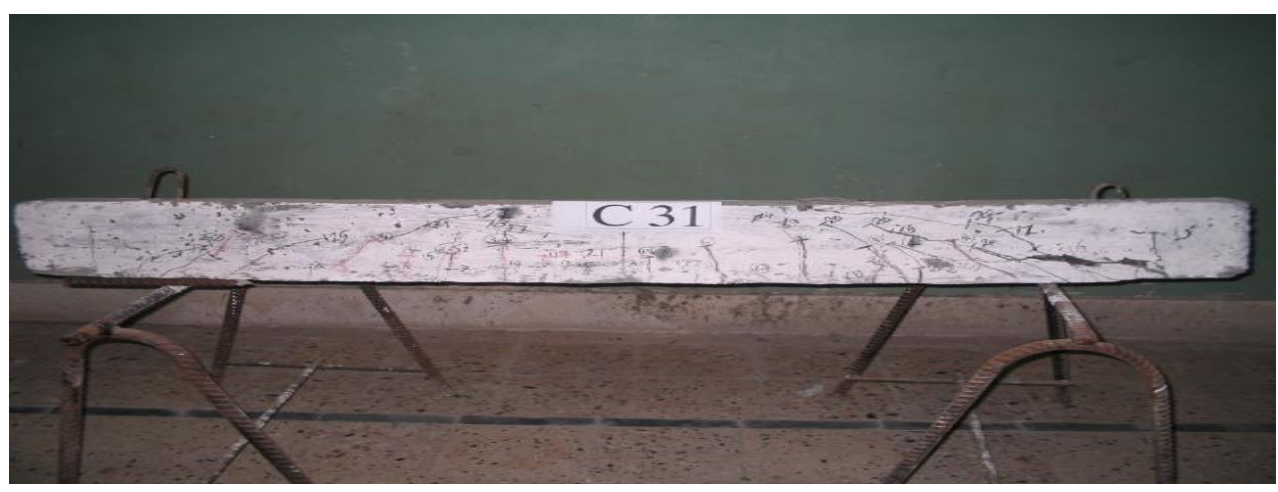

\section{Photo (16): Behavior of Beam C 3-1}

- Note: It is interesting to add that all beams sustained one million cycles and the failure was due to the final static loading test.

\section{B. W.R.T Load deflection diagrams:}

Fig.17, 18 \& 19 shows a plot between the applied loads with the sequence of its applications from zero loading up to failure including the release of loading and reloading after that followed by the final static loading test and the corresponding values of the recorded maximum deflection, maximum concrete strain and maximum values of steel strain. 

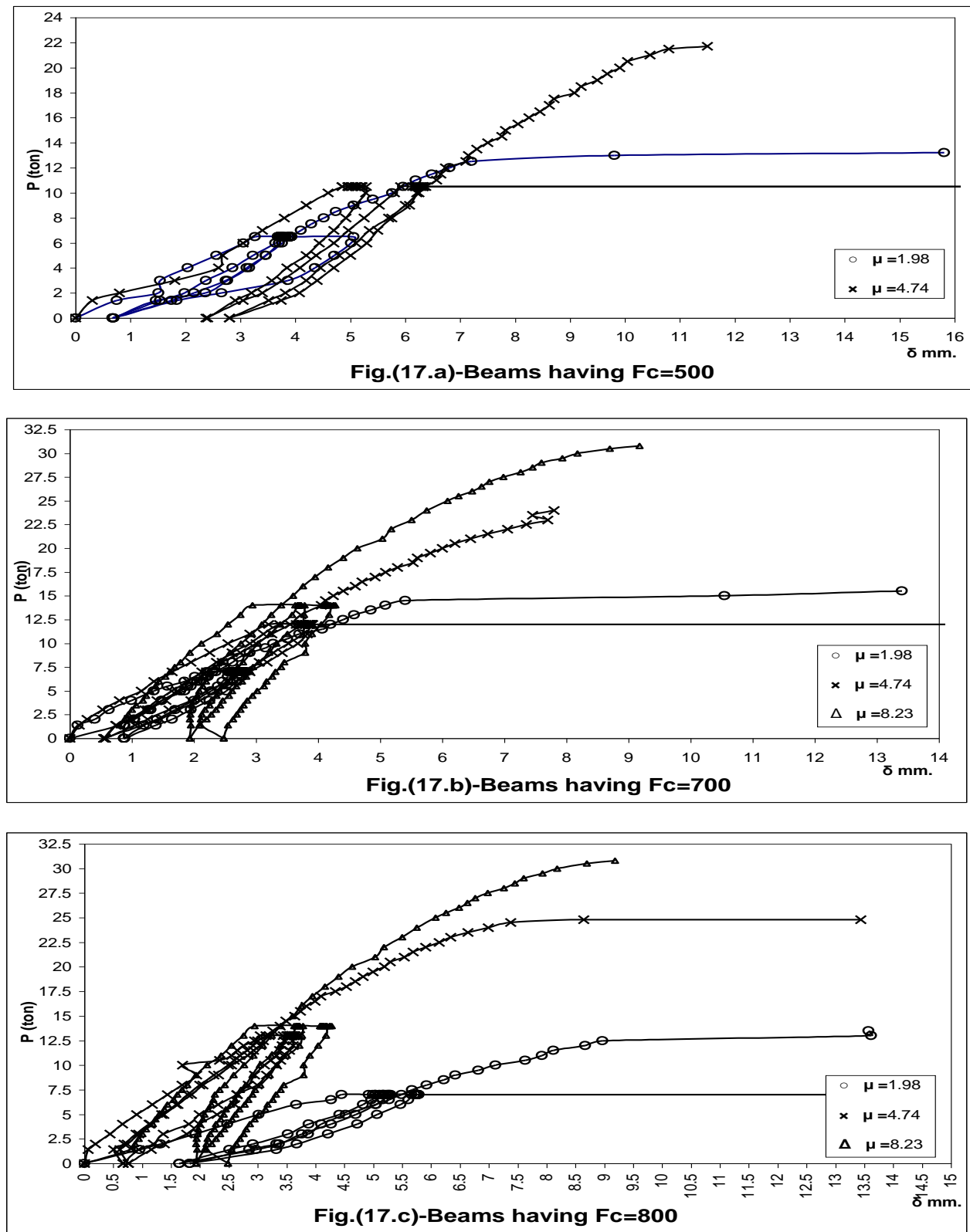

Fig.(17)-Load maximum deflection relationship for repeated loading and final static loading 

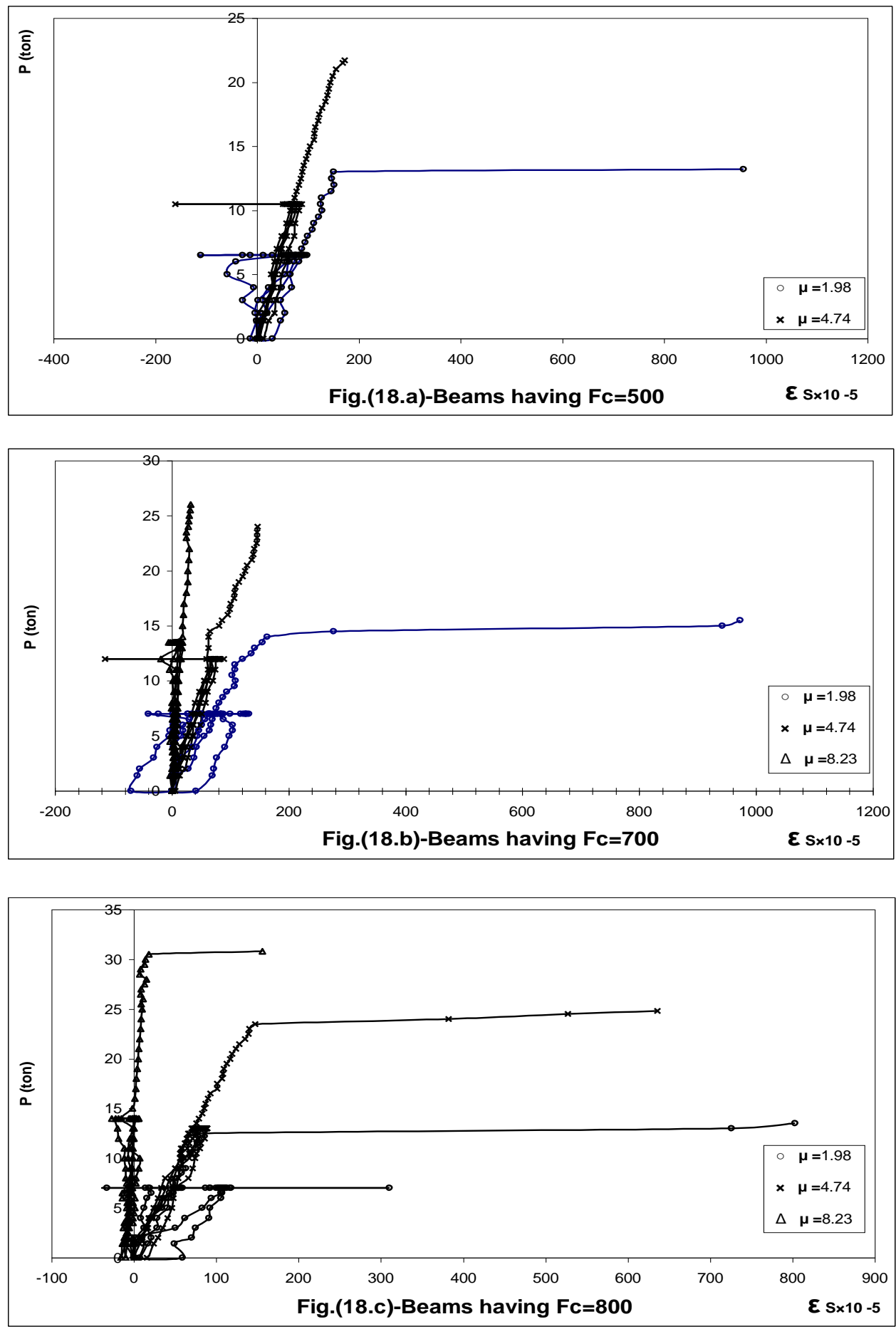

Fig.(18)-Load maximum steel strain relationship for repeated loading and final static loading 

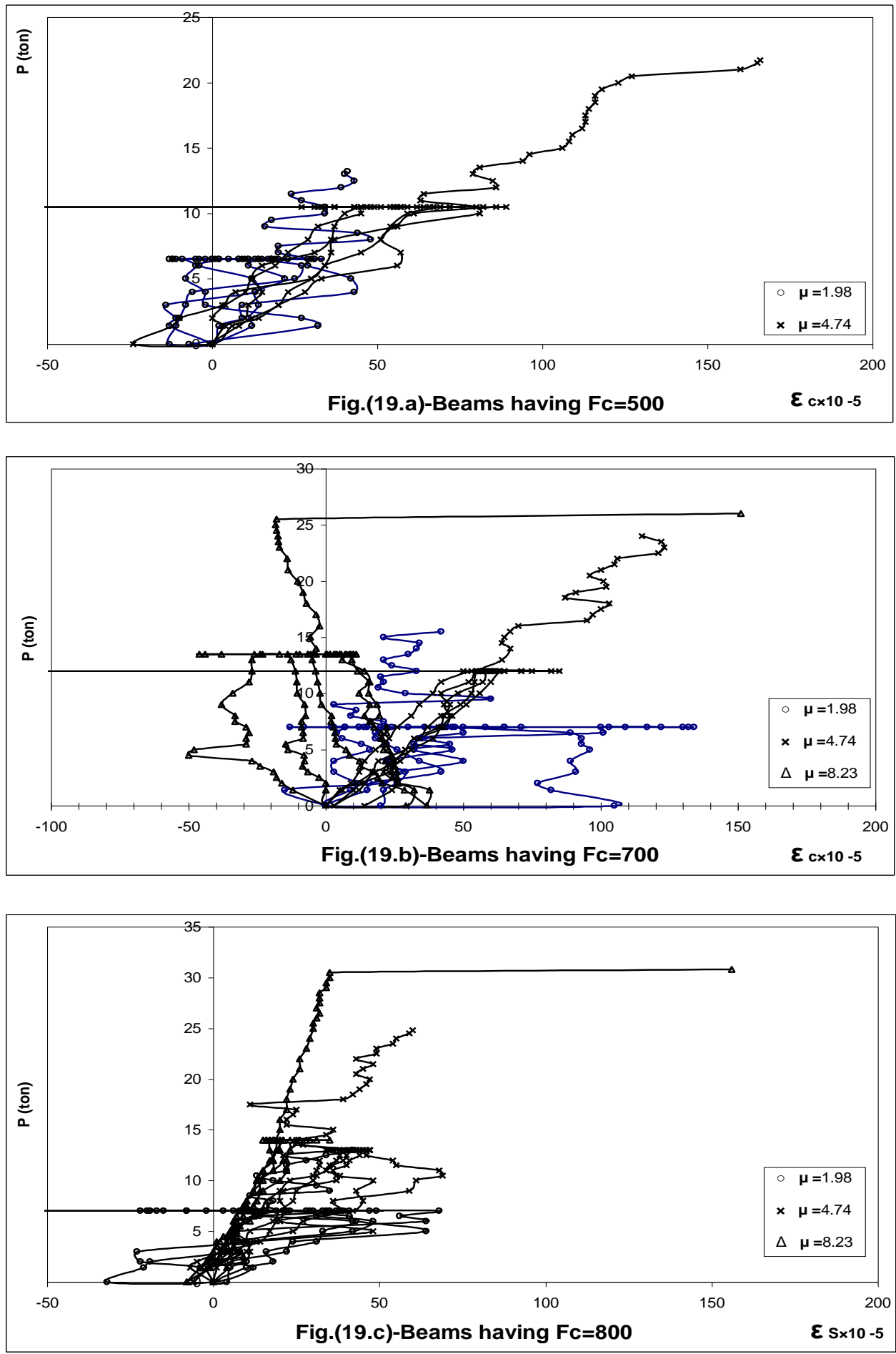

Fig.(19)-Load maximum concrete strain relationship for repeated loading and final static loading 
Table (4) summarizes the obtained values of cracking load, ultimate load, ultimate concrete strain and ultimate steel strain as well as the modes of failure for repeated loading tested beams.

Table ( 4):Test results for repeated loading

\begin{tabular}{|c|c|c|c|c|c|c|c|c|c|c|}
\hline Beam & $\begin{array}{c}\mathrm{Fc} \\
\mathrm{kg} \mid \mathrm{cm} 2\end{array}$ & $\mu \%$ & $\begin{array}{l}\text { Type } \\
\text { of } \\
\text { beam }\end{array}$ & $\begin{array}{l}\text { Pcr } \\
\text { (ton) }\end{array}$ & $\begin{array}{l}\mathrm{Pu} \\
\text { (ton) }\end{array}$ & $\mathrm{Pcr} / \mathrm{Pu}$ & $\begin{array}{c}\text { Maximum } \\
\text { steel strain } \\
\times 10.5\end{array}$ & $\begin{array}{c}\text { Maximumcon } \\
\text { crete strain } \\
\times 10.5\end{array}$ & $\begin{array}{c}\text { Maximum } \\
\text { deflection } \\
(\mathrm{mm})\end{array}$ & Mode of failure \\
\hline A2-2 & \multirow{2}{*}{500} & 1.98 & under & 6.5 & 13.2 & 0.49 & 956 & 48 & 15.2 & Flexural-compression \\
\hline A1-2 & & 4.74 & over & 6.8 & 21.7 & 0.31 & 169 & 166 & 8.7 & Shear \\
\hline B2-2 & \multirow{3}{*}{700} & 1.98 & under & 4 & 15.5 & 0.26 & 973 & 60 & 12.53 & Flexural-compression \\
\hline B1-2 & & 4.74 & over & 5.5 & 24.2 & 0.23 & 147 & 120 & 7.23 & Shear-compression \\
\hline B3-1 & & 8.23 & over & 6.5 & 26 & 0.25 & 32 & 54.6 & 8.41 & Shear-compression \\
\hline C2-2 & \multirow{3}{*}{800} & 1.98 & under & 3 & 13.5 & 0.22 & 869 & 42 & 12.32 & Flexural-compression \\
\hline C1-2 & & 4.74 & over & 3.6 & 24.8 & 0.15 & 636 & 60 & 8 & Flexural-compression \\
\hline C3-1 & & 8.23 & over & 7 & 30.8 & 0.23 & 33 & 43 & 7.25 & Shear-compression \\
\hline
\end{tabular}

Fig.(20)to (31) declared how the \% of main steel as well as the grade of concrete affect the behaviour of such beam tested under repeated load and cracking load $\left(\mathrm{P}_{\mathrm{cr}}\right)$, ultimate final static load $\left(\mathrm{P}_{\mathrm{u}}\right)$, \% of $\left(\mathrm{P}_{\mathrm{cr}} / \mathrm{P}_{\mathrm{u}}\right)$ and ultimate deformation of concrete and steel. Investigation of such figures and table (4) led to the following effects:

\section{a) Effect of Main Steel Percentage ( $\mu \%$ )on:}

\section{- W.R.T Cracks and Final Modes of Failure}

At grade of concrete $F_{c}=500$, The increasing of main steel percentage $(\mu)$ change the mode of failure from flexural-compression failure to shear failure but at $F_{c}=700$ the increase of main steel percentage $(\mu)$ from 4.74 to 8.23 showed no change on the mode of failure (shear-compression mode),but the increase of $\mu$ from 1.98 to 4.74 changed the mode of failure from flexural-compression failure to shear-compression failure. Main while at $F_{c}=800$ the increase of main steel percentage $(\mu)$ from 1.98 to 4.74 had no change on the mode of failure (flexural-compression mode),but the increase up to $\mu=8.23 \%$ changed the mode of failure to shear failure one.

\section{- W.R.T Cracking Load}

At the same concrete strength, the increase of main steel percentage increases the cracking load. as shown in fig.(26)

\section{- Ultimate Loading}

At the same concrete strength the increase of main steel percentage increase ultimate load too. as shown in fig.( 27 ) 


\section{- W.R.T \% of Cracking Load to Ultimate Load}

For constant concrete strength the increase of main steel percentage decreases $\%$ of cracking load to ultimate load. as shown in fig.( 28 )

\section{- W.R.T Maximum Deflection}

At constant grade of concrete, the increase of main steel percentage $(\mu)$ decrease the maximum deflection value. as shown in fig.(29)

\section{- W.R.T Maximum Steel Strain.}

At constant grade of concrete $F_{c}$ the increase of main steel percentage $(\mu)$ decreases the maximum steel strain value. as shown in fig. ( 30 )

\section{- W.R.T Maximum Concrete Strain.}

For constant grade of concrete, the increase of main steel percentage ( $\mu$ ) up to $4.74 \%$ increases the maximum concrete strain value but beyond this value a decrease in the concrete strain value was noticed. as shown in fig.(31)

\section{b) Effect of Grade of Concrete (Fc) on:}

\section{- W.R.T Cracks and Final Modes of Failure}

At same main steel percentage $\mu \%=1.98$ the increase of grade of concrete has no effect on the mode of failure. It was flexural-compression mode. At $\mu=4.74$ the increase of grade of concrete changed the mode of failure from shear failure to shear-compression to flexural-compression failure. At $\mu=8.23$ the increase of grade of concrete changed the mode of failure from shear-compression to shear failure.

\section{- W.R.T Cracking Load}

For the same of main steel percentage, the increase of concrete strength decreased the cracking load but at $\mu \%=8.23$ the increase of grade of concrete increased the cracking load. as shown in fig. ( 20 )

\section{- W.R.T Ultimate Loading}

For the same of main steel percentage, the increase of concrete strength increased the ultimate loading. as shown in fig. ( 21 )

\section{- W.R.T \% Of Cracking Load to Ultimate Load}

For the same of main steel percentage, the increase of concrete strength decreased the $\%$ of cracking load to ultimate load. as shown in fig.( 22 )

\section{- W.R.T Maximum Deflection}

For the same of main steel percentage, the increase of concrete strength decreased the maximum deflection. as shown in fig.( 23 )

\section{- W.R.T Maximum Steel Strain.}

For the same of main steel percentage, $1.98 \%$ the increase of concrete strength decreased the maximum steel strain. Main while at $\mu=4.74$ the increase of grade of concrete from 700 to 800 increased the maximum steel strain as shown in fig.( 24 )

\section{- W.R.T Maximum Concrete Strain.}

For the same of main steel percentage, the increase of concrete strength decreased the maximum concrete strain value as shown in fig. ( 25 ) 


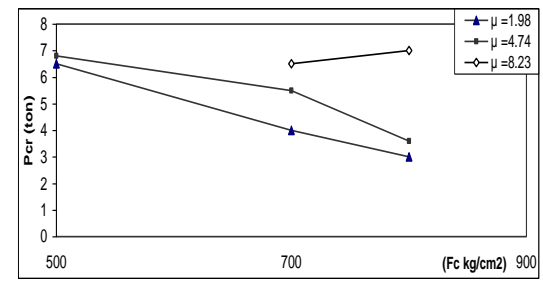

Fig.(20) Relation between cracking load and grade of concrete for repeated loading

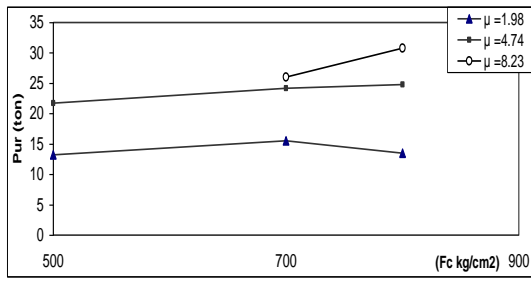

Fig.(21) Relation between ultimat load and grade of concrete for repeated loading

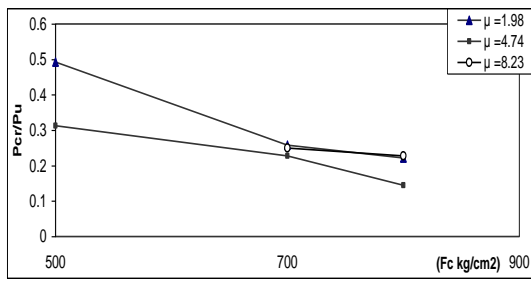

Fig.(22) Relation between Pcr/Pu and grade of concrete for repeated loading

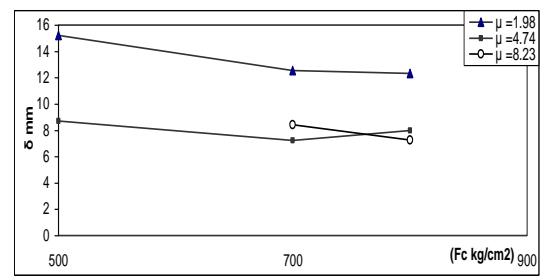

Fig. (23) Relation between max. deflection and grade of concrete for repeated loading

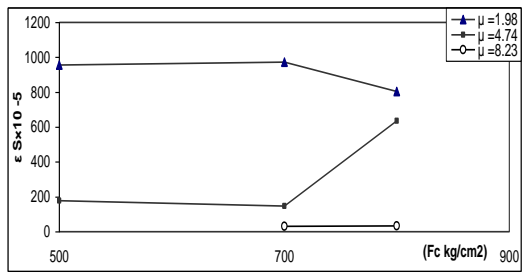

Fig. (24) Relation between max. steel strain and grade of concrete for repeated loading

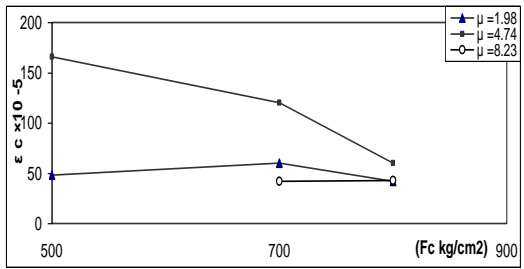

Fig. (25) Relation between max. concrete strain and grade of concrete for repeated loading

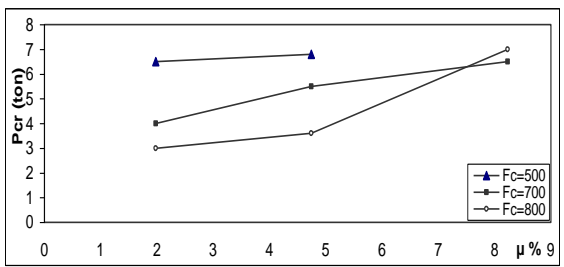

Fig. ( 26 ) Relation between cracking load and \% of reinforcement for repeated loading

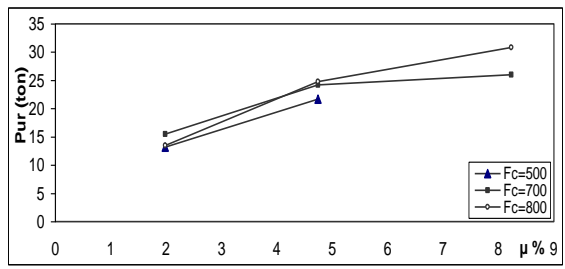

Fig. ( 27 ) Relation between ultimat load and \% of reinforcement for repeated loading

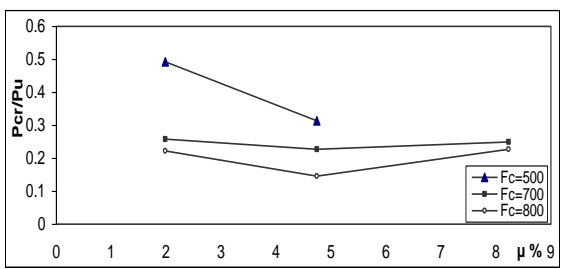

Fig. ( 28 ) Relation between Pcr/Pu and \% of reinforcement for repeated loading

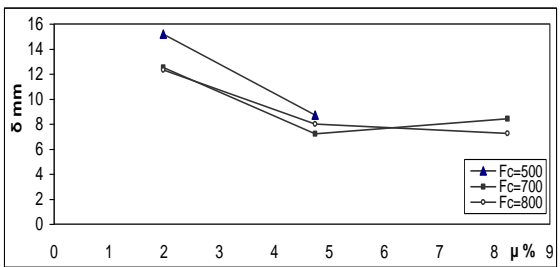

Fig. (29) Relation between max. deflection and \% of reinforcement for repeated loading

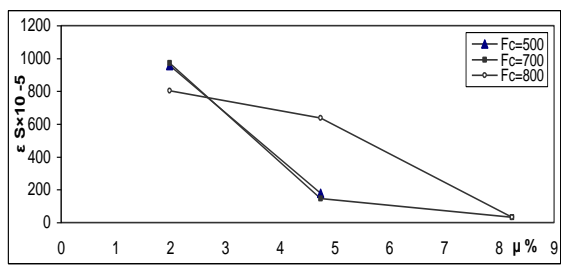

Fig. (30) Relation between max. steel strain and \% of reinforcement for repeated loading

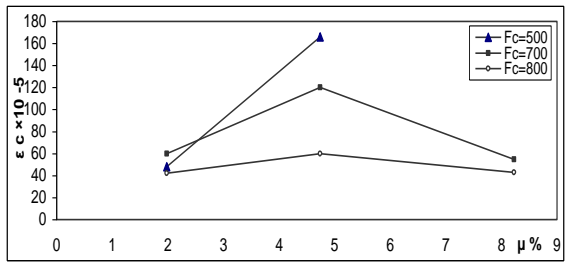

Fig. (31) Relation between max. concrete strain and \% of reinforcement for repeated loading 


\subsection{Comparison Between Beams Tested Under Static and Repeated loading}

Table (5) \& Fig.32-41gives a comparison between the obtained test results for the tested beams under static and repeated loading in terms of the both loading and deformation capacities of these tested beam as affected by both \% of main steel and grade of concrete.

Table ( 5 ):Comparison between beams tested under static and repeated loading

\begin{tabular}{|c|c|c|c|c|c|c|}
\hline Fe kglcm2 & $\mu \%$ & $\begin{array}{c}\text { Type } \\
\text { of } \\
\text { beam }\end{array}$ & $\%$ Pu r/Pu s & $\begin{array}{c}\% \text { of } \\
\text { steel } \\
\text { strain } \\
(\mathbf{r} / \mathbf{s})\end{array}$ & $\begin{array}{c}\text { \%of concrete } \\
\text { strain }(r / s)\end{array}$ & $\delta r / \delta s$ \\
\hline \multirow{2}{*}{500} & 1.98 & under & 105.6 & 124.0 & 10.4 & 199.2 \\
\hline & 4.74 & over & 98.6 & 55.2 & 17.5 & 132.0 \\
\hline \multirow{3}{*}{700} & 1.98 & under & 102.6 & 131.1 & 45.5 & 118.0 \\
\hline & 4.74 & over & 100.4 & 75.8 & 14.8 & 75.0 \\
\hline & 8.23 & over & 94.2 & 23.2 & 37.9 & 60.1 \\
\hline \multirow{3}{*}{800} & 1.98 & under & 96.4 & 92.7 & 10.2 & 84.4 \\
\hline & 4.74 & over & 93.6 & 159.0 & 37.5 & 87.2 \\
\hline & 8.23 & over & 110.4 & 25.0 & 79.6 & 53.3 \\
\hline
\end{tabular}

The comparison reflects the following remarks are observed as shown in fig.(28-37)

\section{- W.R.T Cracks and Final Mode of Failure}

The initial static cycle in all tested beams was carried up to $50 \%$ from the ultimate static load. The intiation of the first crack was observed in the same region nearly as for companion beam tested under static loading. The cycles of repeated loading increases the number of cracks and increases the width of cracks which formed in the static cycles. The modes of failure at many of tested beams more or less have the same shape as mentioned before.

\section{- W.R.T Ultimate Load}

Based on the table (5) and fig. $33 \& 38$, it is obvious that the ratio of (Pur / Pus)\% decreases with increase of concrete grades for beams having $\mu=1.98 \%$ and $4.74 \%$ and increases with increase of grade of concrete for beams having $\mu \%$ higher than $8 \%$.

\section{- W.R.T Ultimate Deflection}

Also fig. $34 \& 39$, shows that the ratio of $(\delta \mathrm{r} / \delta \mathrm{s}) \%$ decreases with increase of concrete grades from 500 to $800 \mathrm{Kg} / \mathrm{cm}^{2}$ disregarding \% of main reinforcements. Mean while for a constant of grade of concrete the higher the \% of main reinforcements the lesser is the corresponding ratio $(\delta \mathrm{r} / \delta \mathrm{s}) \%$. Also it is noticed that for all tested cased this ratio is bigger than $100 \%$.

\section{- W.R.T Ultimate Steel \& Concrete Strain.}

$\operatorname{Fig}(35,36,40 \& 41)$ shows the relation between the ( $\xi \mathrm{sr} / \xi \mathrm{ss}) \%$ as well as the ( $\xi \mathrm{cr} /$ $\xi \mathrm{cs}) \%$ and the corresponding value of either concrete grade or $\%$ of main reinforcement, where it is obvious that these ratio be higher or lesser than $100 \%$ and at the same time it depends on both these parameters. 


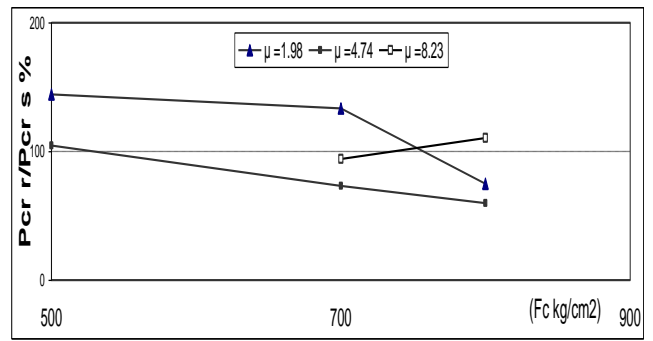

Fig. (32 ) Relation between grade of concrete and \% of cracking load On static and repeated loading

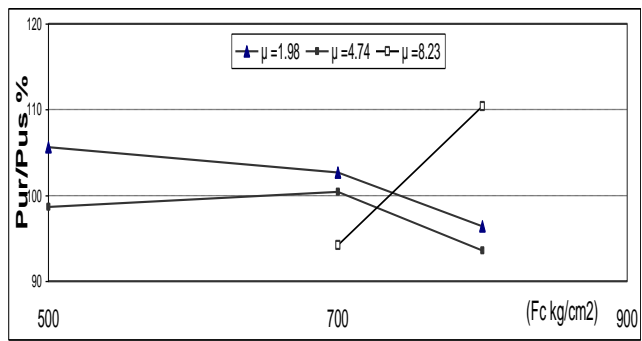

Fig. (33) Relation between grade of concrete and \% of ultimat load On static and repeated loading

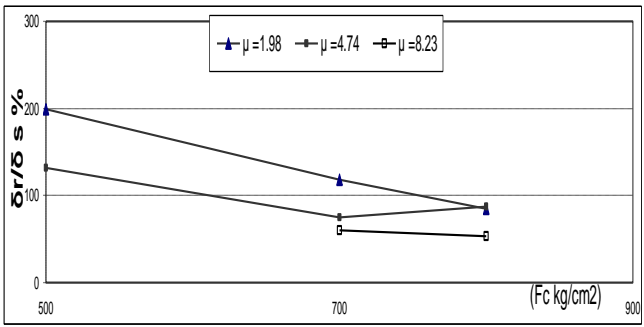

Fig. (34) Relation between grade of concrete and \% of max. deflection On static and repeated loading

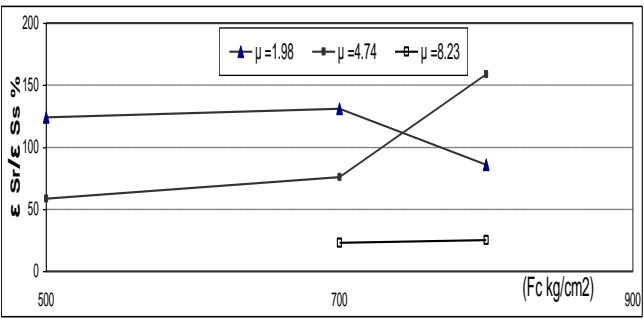

Fig. 35 ) Relation between grade of concrete and \% of max. steel strain On static and repeated loading

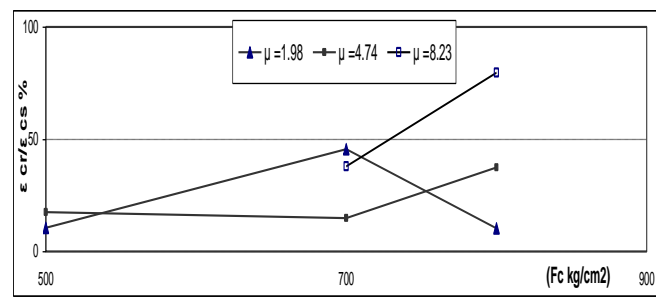

Fig. 36 ) Relation between grade of concrete and \% of max. concrete strain On static and repeated loading

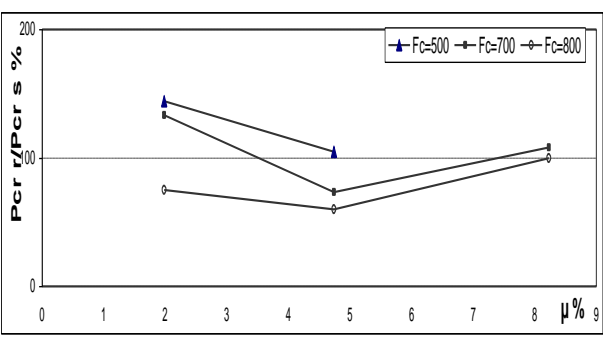

Fig. (37) Relation between \% of reinforcement and \% of cracking load On static and repeated loading

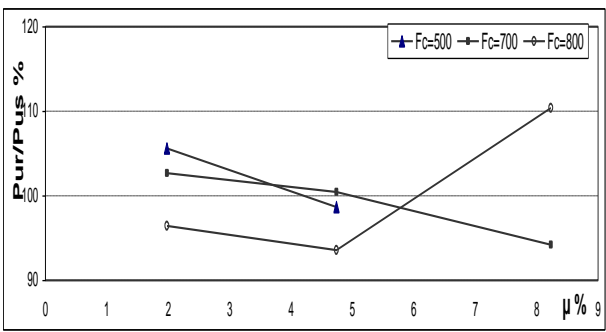

Fig. 38 ) Relation between \% of reinforcement and \% of ulimat load On static and repeated loading

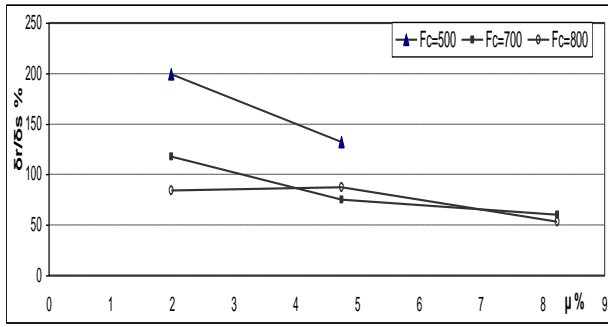

Fig. 39 ) Relation between \% of reinforcement and \% of max. deflection On static and repeated loading

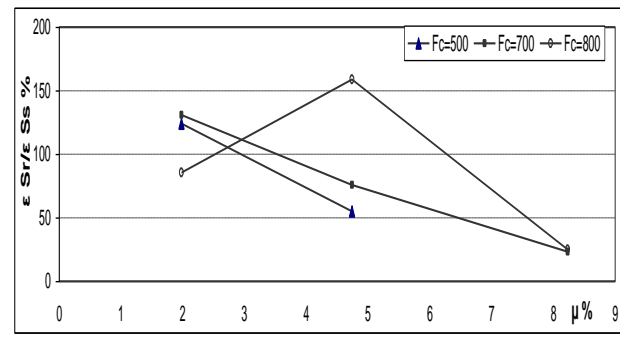

Fig. 40 ) Relation between \% of reinforcement and \% of max. steel strain On static and repeated loading

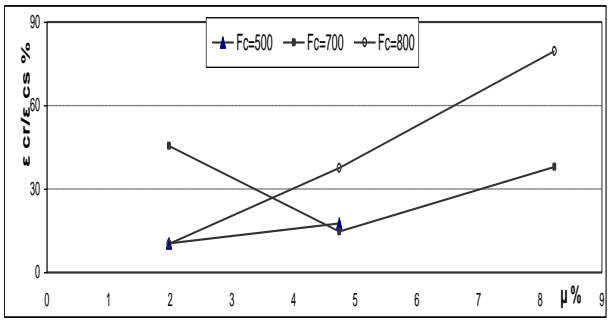

Fig. 41 ) Relation between \% of reinforcement and \% of max. concrete strain On static and repeated loading 


\section{CONCLUSIONS AND REMARKS}

According to here in test results concerning the behavior of high strength over reinforced concrete beams subjected to static and repeated loading, the following conclusions are obtained:

\section{Beams Tested Under Static Loading}

- The values of the cracking and ultimate loads are increased by increasing the main steel ratio and the concrete strength.

- The ratio of cracking load to ultimate load for tested control beams are mainly influenced by the included parameters ( concrete strength (Fcu) and main steel $\operatorname{ratio}(\mu) \%)$.

- The measured values of ultimate deflection increased by decreasing of main steel ratio and by increasing the grade of concrete.

- The maximum concrete strain are increased by increasing of main steel ratio and increasing of concrete grade.

- The maximum steel strain is increased by decreasing of main steel ratio and decreasing of concrete grade.

- The flexural stiffness of the tested beams increased mainly by increasing both of main steel ratio and concrete grade.

- The mode of failure of high strength concrete beams is changed from flexural failure to compression failure to shear failure with gradual increase of main steel ratio but no changes occurred by increasing of concrete grade.

\section{Beams Tested Under Repeated Loading}

- The ultimate final static loads of tested beams increased by increasing of main steel ratio and concrete grade.

- Repeated loading has a pronounced effect on the induced number and width of the initiated secondary cracks throughout the tested beams.

- The final mode of failure for tested beams changed in the same sequence of change of mode of failure as in control beams.

Finally, The behavior of over reinforced high strength concrete beams is more sensitive under repeated loading than that under static loading, where repeated loading has a significant effect on maximum measured deflection and flexural stiffness (ultimate loads and both concrete and steel strains).

\section{REFERENCES}

1- A. A. Mohamed Eid "Behavior of Over Reinforced Concrete Beams" sM.Sc. Thesis .Zagazig University 1991.

2- Abdel Kader T.A. "Behavior of Silica Fume High Strength Reinforced Concrete Beams under Repeated Loading”M.Sc. Thesis .Assiut University 2001.

3- Besler B. and Betro V. "Behvior of Reinforced concrete under Repeated Loading" Journal of the structure Division, ASCE, vol.94 No. st6 „June 1968 
4- Byung Hwanoh "Fatigue Life Distributions of Concrete for Various Stress Levels" ACI Materials Journal, March- April 1991.

5- Clark L. A. and Eastwood W. "The Flexural strength of concrete Beams Reinforced with very high strength steel" Struct. Engineering .vol. 48, no.7, July 1970, pp. 277-282.

6- Hisham H. H. Ibrahim and James G. MacGregor "Flexural Behavior of Laterally Reinforced High Strength Concrete Sections" ACI Structural Journal, NovemberDecember 1996.

7- Khaled A.Mahmoud "Shear Behavior of High Strength Concrete Beams under Static Loading" M.Sc. Thesis Assiut University Egypt, 2000

8- Kriz L. B. and Lee, S. L., "ultimate strength of over reinforced concrete beams" ASCE Engineering Mechanical Division, vol.86 No. EM3, proc. Paper 2502, June 1960, pp.95-105

9- M.Naguibe "Effect of Silica Fume on Concrete" M.Sc., Thesis American University Egypt 1996

10- Mahmoud Imam, Ahmed Abdel-Reheem,and Mahmoud Amin "Utilization of Silica Fume in Egypt" Seventh Arab structural Engineering Conference 24-26 November 1997 Kuwait.

11- Salah El-Din Fahmy Taher, Tarek Mohamed Fawzy "Performance of very high strength concrete subjected to short time repeated Loading" Conference of Minia (14-16) March, 1999. Egypt.

12- Sargin M. "Stress Strain Relationship for concrete and structural concrete sections" Study No. 4, Solid Mechanics Diviation 1971 ,University of Waterloo 'Waterloo, Ontario ,Canada'

13- Sung-Woo.Shin, Kwang-soo. Lee, Jung-IU-Moon and S.K. Ghash "Shear Strength of Reinforcement High Strength Concrete Beams With Shear Span To Depth Ratios between 1.5 and 2.5" ACI Materials Journal, July- August 1999.

14- Verna, J.R. and strelson "Repeated Loading Effect on Ultimate Static Strength of Concrete Beams” ACI Journal vol.60, June 1963 pp. 743-750.

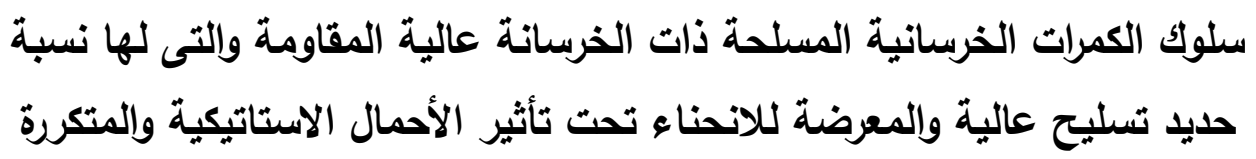

فى هذا البحث تم اجراء دراسة عملية لسلوك الكمرات الخرسانية المسلحة ذات المقاومة العالية ونسبة

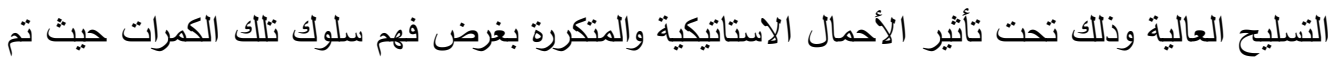
دراسة عدد (16) كمرة لها نسب تسليح مختلفة ورتب خرسانة مختلفة ومعرضة لاحمال مختلفة وذللك بدراسة أثز العوامل التالية على سلوك الكمرات: 


$$
\text { رتبة الخرسانة (500, 700, } 800 \text { كجم/سم²) }
$$

نسبة حديد التسليح الرئيسى( نوع الحمل (استاتيكى ومتكرر)

حيث تم قياس الانفعال الحادث فى كل من الخرسانة والحديد وكذلك الترخيم وشكل الثروخ وأقصى

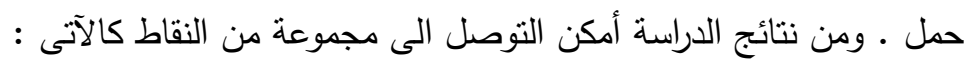

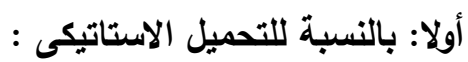

تزداد قيم أحمال التشريخ وأقصى حمل مع زيادة نسبة حديد التسليح ورتبة الخرسانة

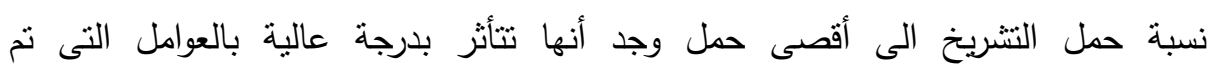
دراستها (رتبة الخرسانة ونسبة الحديد)

تزداد قيم التزخيم كلما نقصت نسبة حديد التسليح وزادت رنبة الخرسانة ونسبة الفيدانة

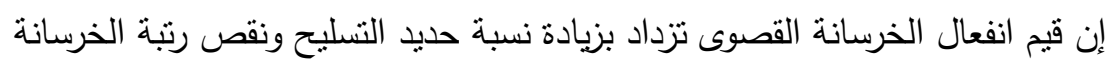
بينما قيم انفعال الصلب القصوى تزداد مع نقص نسبة حديد التسليح وزيادة رتبة الخرسانة

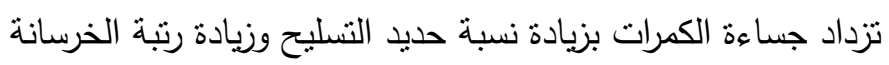

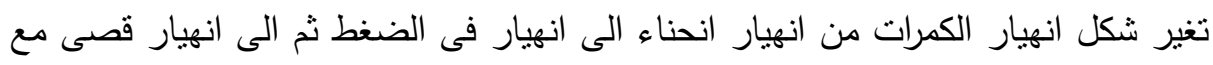

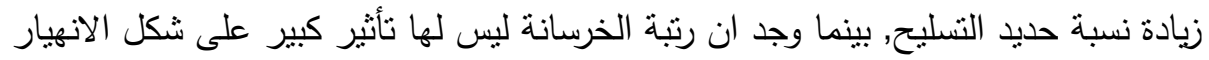

ثانيا: بالنسبة للاحمال المتكررة أقصى حمل استاتيكى نهائي مصاحب للأحمال المتكررة يزداد بزيادة نسبة حديد التسليح ورتبة الخرسانة

الأحمال المتكررة لها تأثيركبير على عدد وعرض الثروخ الثانوية المتولدة تغير شكل الانهيار للكمرات تحت تأثير الأحمال المتكررة بنفس التتابع للكمرات المناظرة تحت تأثير الأحمال الاستاتيكية ان سلوك الكمرات الخرسانية ذات المقاومة العالية والتى لها نسب حديد عالية يتأثر بدرجة كبيرة

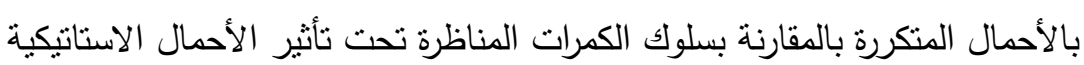

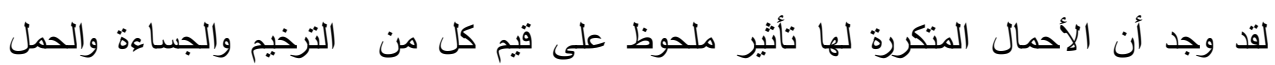

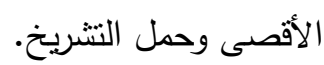

